Ocean Sci. Discuss., 7, 207-249, 2010

www.ocean-sci-discuss.net/7/207/2010/

(C) Author(s) 2010. This work is distributed under

the Creative Commons Attribution 3.0 License.

This discussion paper is/has been under review for the journal Ocean Science (OS). Please refer to the corresponding final paper in OS if available.
Wind forcing effects on coastal circulation

P. De Gaetano et al.

\section{Wind forcing effects on coastal circulation and eddy formation around a cape}

\section{P. De Gaetano ${ }^{1}$, M. Burlando ${ }^{1}$, A. M. Doglioli ${ }^{2}$, and A. A. Petrenko ${ }^{2}$}

${ }^{1}$ Dipartimento di Fisica, Università di Genova, Genoa, Italy

${ }^{2}$ Aix-Marseille Université, CNRS, Laboratoire d'Océanographie Physique et de Biogéochimique, UMR 6535, OSU/Centre d'Océanologie de Marseille, Marseille, France

Received: 15 December 2009 - Accepted: 11 January 2010 - Published: 2 February 2010

Correspondence to: P. De Gaetano (degaetano@fisica.unige.it)

Published by Copernicus Publications on behalf of the European Geosciences Union.

\section{Title Page}

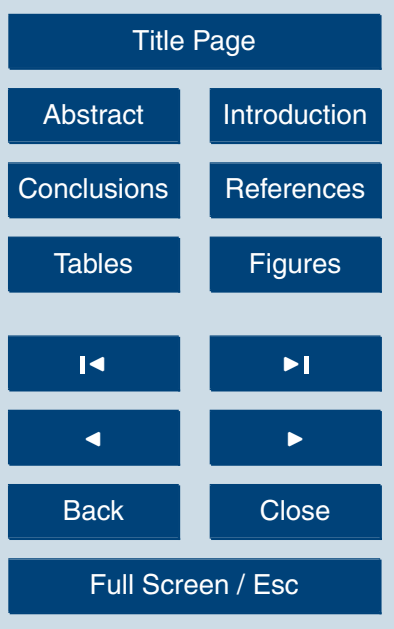

Printer-friendly Version

Interactive Discussion 


\section{Abstract}

This numerical study aims to assess the role of the wind stress and its resolution on the coastal circulation around the Promontorio of Portofino, a blunt cape in the Ligurian Sea (Northwestern Mediterranean). A high-resolution hydrodynamical numerical model, 5 forced at the inflow open boundary by a coarser regional model, is run in three different configurations: no wind, $21-\mathrm{km}$ and $7-\mathrm{km}$ resolution winds. Moreover, the effect of using different values for the drag coefficient in the wind stress formulation is also tested. Sensitivity analysis of the mass transport and of the current velocity highlights that the greater effect of the wind is near the coast and the higher resolution wind forcing increases the intensity of a coastal countercurrent and of an eddy in the lee of the cape. A cluster analysis is performed to distinguish the main wind patterns and the main coastal flow patterns in the area under study for 2001-2003. It is shown that the typical wind regimes are coherent with the current ones highlighting the key role played by the wind in enhancing the coastal dynamics and the eddy formation around 15 the cape.

\section{Introduction}

The importance of the wind speed and wind stress curl on the formation of basin-scale gyres is already shown by several authors as Moskalenko (1974); Malanotte-Rizzoli and Bergamasco (1989, 1991); Herbaut et al. (1996); Pinardi and Navarra (1993). More recently, Molcard et al. (2002) shows that the wind forcing can generate upper ocean gyres of observed structure and strength. As the wind forces the coastal circulation, the interaction between the wind and the coastal topography, such as headlands and capes, is shown to have a strong effect on shallow water hydrodynamics (e.g., Castelao and Barth, 2007, 2006). In particular, topographically-induced changes in wind speed and wind stress curl are usually associated with flow variability, formation and growth of instabilities around promontories. Moreover, the coastal circulation is highly
OSD

7, 207-249, 2010

\section{Wind forcing effects} on coastal circulation

P. De Gaetano et al.

\section{Title Page}

Abstract Introduction

Conclusions References

Tables Figures

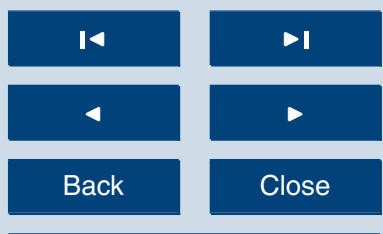

Full Screen / Esc

Printer-friendly Version

Interactive Discussion 
influenced by the shape of the coastline. Leeward eddies is observed behind topographic structures like prominent headlands and capes (e.g., Pattiaratchi et al., 1986; Farmer et al., 2002; McCabe and Pawlak, 2006). These eddies have a strong impact on the dynamics of coastal systems, playing a role in biological, ecological, and geolog5 ical processes. Leeward eddies affect the dispersion of dissolved pollutants (Hayward and Mantyla, 1990; Doglioli et al., 2004b; De Gaetano et al., 2008), floating organisms (Chiswell and Roemmich, 1998; Roughan et al., 2005; Rankin et al., 1994; Murdoch, 1989), nutrients (John and Pond, 1992), and sediments (Pingree, 1978; Bastos et al., 2002, 2003; Jones et al., 2006). From a dynamical point of view, capes and headlands 10 are important for the circulation because they are associated with enhanced mixing, drag and dissipation (Farmer et al., 2002; Pawlak et al., 2003). All the processes usually observed around capes, like current separation, formation of eddies and generation of lee waves, also affect the larger-scale coastal currents through the enhancement of the drag force.

15 A very large branch of the scientific literature focuses on the phenomenon of coastal current separation and eddy formation behind capes, in terms of experimental, numerical and theoretical investigations (e.g., Boyer and Tao, 1987; Freeland, 1990; Geyer, 1993; Denniss et al., 1995; Sadoux et al., 2000). Some of these studies, which mainly regard the effect of islands on the flow, focus on the limit of very deep water (e.g., Coutis and Middleton, 2002). However, most of the literature focuses on the eddy formation in shallow-water environments, where vertically averaged 2-dimensional dynamics is an appropriate approximation (e.g., Verron et al., 1991; Davies et al., 1995), often considering highly energetic, time-dependent tidal currents and idealized smooth cape structures (Signell and Geyer, 1991).

The present study follows this kind of mathematical approach. In particular, we want to study the relation between wind forcing and eddy formation as a function of the wind flow resolution. The importance of the wind forcing is recognized by many authors, but its effect on the coastal circulation is not quantified yet. Moreover, complex orography in coastal area can strongly influence the local wind (Esposito and Manzella, 1982) and
OSD

$7,207-249,2010$

\section{Wind forcing effects on coastal circulation}

P. De Gaetano et al.

\section{Title Page}

Abstract Introduction

Conclusions References

Tables Figures

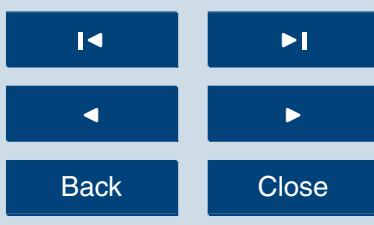

Full Screen / Esc

Printer-friendly Version

Interactive Discussion 
the associated oceanic circulation. In this work, we consider the coastal area of the Promontorio of Portofino, a blunt headland with an abrupt rising from the ocean with very steep slopes. It is located along the Ligurian coast in the North-Western Mediterranean Sea. This choice is due to the great importance of this area both for tourism 5 and commercial activities as well as for its great natural environmental value. Since 1998, the Promontorio of Portofino and its surroundings have been declared Marine Protected Park, with the intent of preserving the coastal and marine ecosystem. Many political and social conflicts have arisen since then, due to the contrast between the high tourist pressure and the need for a sustainable management of natural resources 10 (Salmona and Veradi, 2001). In this framework, an understanding of the local coastal circulation and its impact on the transport of pollutants deriving from antrophogenic activities (e.g., Aliani et al., 2003; Doglioli et al., 2004b; De Gaetano et al., 2008) is of great importance in order to correctly manage the maritime and coastal areas of the park.

15 The present paper is organized in six main sections. In Sect. 2 an overview of the meteorology and of the ocean circulation in the northwestern Mediterranean is presented. Section 3 reports a description of the atmospheric and ocean model setup used to simulate the coastal currents in the area under study. Moreover, a description of the cluster analysis, used to analyze the results, is reported. The main results of the numerical experiments are then presented in Sect. 4. Discussion and conclusions are drawn in Sects. 5 and 6, respectively.

\section{Main atmospheric and ocean-circulation patterns of the Northwestern Mediterranean}

The Western Mediterranean Basin is characterized by Mistral events and strong cy25

clo clogenesis activity over the Balearic Sea and in the lee of the Alps during winter, and extended high-pressure situations all over the Mediterranean during summer, related to the summer monsoons over West Africa, East Africa, and Asia (Burlando, 2008). The
OSD

$7,207-249,2010$

Wind forcing effects on coastal circulation

P. De Gaetano et al.

\section{Title Page}

Abstract Introduction

Conclusions References

Tables Figures

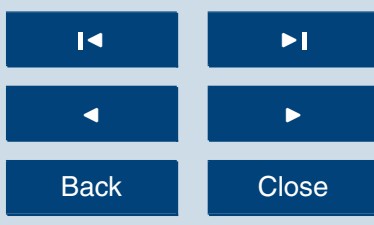

Full Screen / Esc

Printer-friendly Version

Interactive Discussion 
Mistral wind is the predominant air mass blowing over the western Mediterranean basin in winter and it is a cold, dry, continental wind initially blowing over the Gulf of Lions and the Ligurian-Provencal basin (May, 1982). As far as the Ligurian area is concerned, a statistical analysis of the wind measured in Genoa shows that, in winter (summer), 5 the winds are generally northerly or north-easterly (southerly) (Esposito and Manzella, 1982). Moreover, as expected, the comparison among the wind speed and direction distributions corresponding to measurements recorded at Genoa, Pisa and Nice shows that they are strongly influenced by the surrounding orography (Alps and Appennines). The characteristics of water masses in the Ligurian Sea are thought to be tightly con10 nected to the aforementioned wind regimes. As far as the ocean circulation in the area under study is concerned, the Ligurian coastal circulation is part of the general cyclonic circulation of the Mediterranean Sea (Castellari et al., 2000; Molcard et al., 2002), with a thermal front dividing the warmer coastal water from the colder water in the interior. The general cyclonic circulation is also characterized by a seasonal cycle correlated to tal observations and numerical simulations (e.g., Astraldi and Gasparini, 1992). This seasonality mostly consists in intense vertical water movements taking place in winter as a consequence of the strong air-sea interaction processes induced by the Mistral events (Group, 1970; Bunker, 1972), which in turn affect the all-depth basin circulation 20 (Taupier-Letage and Millot, 1986; Astraldi and Manzella, 1983). The eastern part of the Ligurian sea appears to play an important role for the comprehension of the dynamic characteristics of the basin. Astraldi et al. (1990) show that two currents converge in that region, coming from the north-west side of Corsica (West Corsican Current) and the Corsican Channel (Tyrrhenian Current). Though both flowing northward, they differ in some basic properties: whereas the West Corsican Current maintains almost stable features year round, the warmer Tyrrhenian Current is more energetic in winter than in summer, which gives it a strong seasonal signal. Historical measurements of the coastal current upstream of the Promontorio of Portofino are available in terms of long currentmeter time series and hydrographic surveys (Esposito and Manzella, 1982; As-
OSD

7, 207-249, 2010

\section{Wind forcing effects on coastal circulation}

P. De Gaetano et al.

\section{Title Page}

Abstract Introduction

Conclusions References

Tables Figures

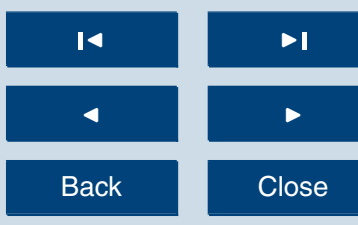

Full Screen / Esc

Printer-friendly Version

Interactive Discussion 
traldi and Manzella, 1983; Astraldi and Gasparini, 1986). They indicate the existence of a northwestward current flowing approximately along the isobaths and following the narrow shelf. The current appears well organized and consistent, at least during the winter period when the wind blowing from north-east reinforces the general circulation 5 of the Ligurian Sea. The transport is approximately of $0.3 \mathrm{~Sv}$ on the shelf. The in situ measurements (Astraldi and Gasparini, 1986) and the numerical study (Doglioli et al., 2004a) highlight the presence of an anticyclonic eddy in the lee of the cape. The eddy appears persistent for a period of the order of a month, at least in the winter period. A coastal southeastward countercurrent is present during the summer in the Gulf of

10 Genoa and it is associated to periods of prevailing southerly winds. It is a drift current which characteristics depend on the coastal curvature (Esposito and Manzella, 1982). Moreover, Esposito and Manzella (1982) find that the shelf circulation is forced by the deep basin circulation and the local wind that has a high variability both in intensity and direction, largely to be attributed to the land morphology (Bruschi and Manzella, 1980).

\section{Numerical and statistical methods}

In this study, the outputs of two versions with two different horizontal resolutions of an atmospheric model are used to force a coastal ocean model. In the following, a description of the main characteristics of these models and their interaction is given (Sects. 3.1 and 3.2). Moreover, in Sect. 3.3 the methodology adopted to perform the cluster anal20 ysis is also shortly described.

\subsection{Atmospheric modelling setup}

The atmospheric model BOLAM (BOlogna Limited Area Model) is a hydrostatic primitive equation meteorological model, developed at the Institute of Atmospheric Sciences and Climate (ISAC) of the Italian National Research Council (CNR) of Bologna (Buzzi et al., 1994). It is used for weather forecasting at the Meteo - Hydrological Centre for Civil Protection (CFMI-PC) of the Ligurian Region, at the Department of Physics of the

OSD

7, 207-249, 2010

\section{Wind forcing effects} on coastal circulation

P. De Gaetano et al.

\section{Title Page}

Abstract Introduction

Conclusions References

Tables Figures

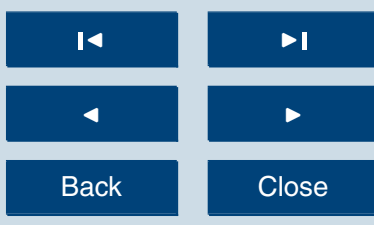

Full Screen / Esc

Printer-friendly Version

Interactive Discussion 
University of Genoa, and at the National Observatory of Athens. It is a grid point, hydrostatic model in sigma coordinates, computing zonal and meridional wind components, potential temperature, specific humidity and surface pressure as prognostic variables. Horizontal discretization adopts the Arakawa C-grid, while the vertical discretization 5 is of Lorenz type, with a variable spacing such as to give higher resolution near the surface and, to a smaller extent, near the tropopause. The boundary-layer scheme parameterizing momentum, latent and sensible heat turbulent fluxes at the surface is based on the drag coefficient formulation. Exchange coefficients are represented by analytic formulae dependent on the Richardson number and on the roughness and 10 mixing lengths (Louis et al., 1982).

Surface roughness length is different for momentum and latent-sensible heat over land. It is also dependent on orography height in order to parameterize aerodynamic drag. Charnock's (1955) formula is used to parameterize roughness length over sea and is the same for both momentum and heat parameters. Geleyn (1988) vertical in-

terpolation scheme is used to find wind at 10-m height using surface pressure and the wind, temperature and specific humidity at the lowest model level and at the surface. A fourth-order horizontal diffusion term (for numerical stability) based on the spatial operator is added to all prognostic equations except for the tendency of surface pressure (Buzzi et al., 1998). This procedure, adopted by all numerical modelers, has strong impact on surface wind, leading to a systematic underestimation of the wind speed (Chèruy et al., 2004). For the time period of the present analysis, namely from January 2001 to December 2003, we have used two versions of this model running at CFMI-PC with different computational domain (Fig. 1) and horizontal resolutions:

- a coarser version covering all the western Mediterranean Basin with a horizontal resolution of $21 \mathrm{~km}$ (BOLAM 21 hereafter), running with analysis and forecasts of the ECMWF operational model as initial and boundary conditions;

- a finer version covering the Northern Italy with a horizontal resolution of $7 \mathrm{~km}$ (BOLAM 7 hereafter), one-way nested into the BOLAM 21 version.
OSD

7, 207-249, 2010

\section{Wind forcing effects} on coastal circulation

P. De Gaetano et al.

\section{Title Page}

Abstract Introduction

Conclusions References

Tables Figures

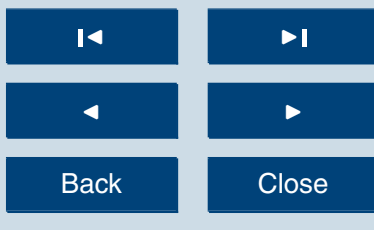

Full Screen / Esc

Printer-friendly Version

Interactive Discussion 
Both models provided the wind forcing to the ocean model with a time-step of three hours (at 00:00, 03:00,.., 21:00 UTC).

\subsection{Coastal ocean modelling setup}

The coastal circulation high-resolution numerical model POM (Blumberg and Mellor, 5 1987), in its barotropic version, is used to simulate the circulation around the Promontorio of Portofino, a blunt cape in the Ligurian Sea (Northwestern Mediterranean, Fig. 2). $\mathrm{POM}$ is a primitive equation, free surface, sigma coordinate ocean model, based on Boussinesq and hydrostatic approximations. Sigma coordinates are particularly useful in coastal applications because they resolve bottom boundary layer processes. In our

implementation the horizontal components of depth-averaged current are computed on an Arakawa-C grid and the vertical turbulence closure is based on the Mellor and Yamada (1982) model.

Since the primary focus of this study is to assess the effect of wind resolution on coastal currents and since the circulation in this area is mainly barotropic (Bruschi and

15 Manzella, 1980; Astraldi and Manzella, 1983), we choose to consider the barotropic version of the POM model.

The numerical mesh, rotated by 27 degrees anti-clockwise with respect to the true north, consists of $200 \times 100$ grid points. The coastline and bathymetry data were downloaded on the web site http://rimmer.ngdc.noaa.gov/mgg/coast/getcoast.html and 20 http://pdas.navo.navy.mil, respectively. The horizontal resolution varies in the numerical domain: a finer resolution of $500 \mathrm{~m}$ is used in the area closer to the headland to better resolve the dynamics around Portofino. In Fig. 2 the POM domain is shown.

We consider the same POM set-up already validated by Doglioli et al. (2004a): at the western (outcoming) and at the southern boundaries a radiation boundary con25 ditions and a free sleep wall are considered, respectively. At the eastern (incoming) boundary, instead of the condition in Flather (1976) used by Doglioli et al. (2004a), we consider the along-shore component of the depth-averaged current and the surface
OSD

$7,207-249,2010$

\section{Wind forcing effects on coastal circulation}

P. De Gaetano et al.

\section{Title Page}

Abstract Introduction

Conclusions References

Tables Figures

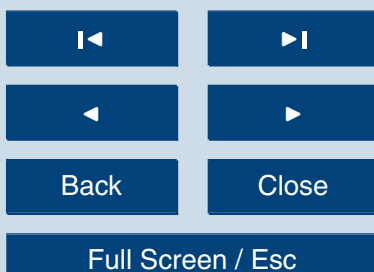

Printer-friendly Version

Interactive Discussion 
elevation computed by the regional model Symphonie. This improves the reliability of the model and highlights the seasonal nature and the high temporal variability of the coastal current.

The Symphonie model is an hydrostatic sigma-coordinate free-surface ocean model 5 developed at the Pole Oceanographie Cotiere (CNRS and Université de Toulouse, Marsaleix et al., 2008). It computes the Western Mediterranean circulation from 2001 to 2003 with a horizontal spatial resolution of $3 \mathrm{~km}$ (Hu et al., 2009). Symphonie is itself forced by MFS model (Pinardi et al., 2003).

The circulation in the studied area is characterized by the presence of a northwest10 ward current flowing approximately along the isobath and following the narrow shelf, with some periods of reversal (Astraldi and Manzella, 1983; Astraldi et al., 1990; Baldi et al., 1997). These characteristics are well reproduced by the Symphonie model. Indeed at the cross-shore transect representing the POM eastern boundary, we compute the surface elevation and the along-shore and cross-shore components of the depth15 averaged current following the same method of Astraldi and Manzella (1983) for the in situ measurements. We obtain the values ranging between $-0.01 \mathrm{~m}$ to $0.12 \mathrm{~m}$, between $-0.37 \mathrm{~m} \mathrm{~s}^{-1}$ to $0.22 \mathrm{~m} \mathrm{~s}^{-1}$ and between $-0.08 \mathrm{~m} \mathrm{~s}^{-1}$ to $0.01 \mathrm{~m} \mathrm{~s}^{-1}$, respectively. These obtained values show a prevalence of the westward transport with some period of reversal especially in the summer period.

The wind fields at $10 \mathrm{~m}$ above the sea level (a.s.l.) provided by BOLAM model, are utilized as surface condition for the POM model. The wind data computed by BOLAM 21 and BOLAM 7 also over the POM domain, are horizontally interpolated to match the POM resolution.

The wind stress $\boldsymbol{\tau}_{\mathrm{w}}$ is computed using the classical bulk formula:

${ }_{25} \quad \boldsymbol{\tau}_{\mathrm{w}}=\frac{\rho_{\mathrm{ar}}}{\rho_{\mathrm{wr}}} C_{\mathrm{D}} \boldsymbol{w}_{10}^{2}$

where $\boldsymbol{w}_{10}$ is the interpolated wind speed at 10 ma.s.l., $\rho_{\mathrm{ar}}$ and $\rho_{\mathrm{wr}}$ are the air and water density, respectively.
OSD

7, 207-249, 2010

\section{Wind forcing effects} on coastal circulation

P. De Gaetano et al.

\section{Title Page}

Abstract Introduction

Conclusions References

Tables Figures

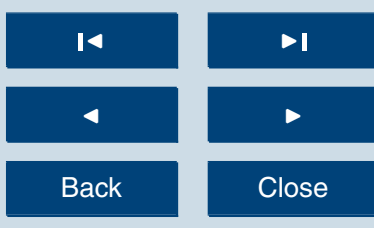

Full Screen / Esc

Printer-friendly Version

Interactive Discussion 
We perform two different simulation sets, varying the drag coefficient $C_{\mathrm{D}}$ value. In the first set, the drag coefficient is fixed to the value $C_{D}=10^{-3}$. In the second set, the drag coefficient value varied with the wind speed variations as proposed by Csanady (1982):

$C_{\mathrm{D}}=1.6 \times 10^{-3} \quad w_{10} \leqslant 7 \mathrm{~m} \mathrm{~s}^{-1}$

${ }_{5} \quad C_{\mathrm{D}}=2.5 \times 10^{-3} \quad w_{10}>10 \mathrm{~m} \mathrm{~s}^{-1}$

To fill the wind values between 7 and $10 \mathrm{~m} \mathrm{~s}^{-1}$, the $C_{\mathrm{D}}$ value has been calculated linearly:

$C_{\mathrm{D}}=1.9 \times 10^{-3} \quad 7 \mathrm{~m} \mathrm{~s}^{-1}<w_{10} \leqslant 8.5 \mathrm{~m} \mathrm{~s}^{-1}$

$C_{\mathrm{D}}=2.2 \times 10^{-3} \quad 8.5 \mathrm{~m} \mathrm{~s}^{-1}<w_{10} \leqslant 10 \mathrm{~m} \mathrm{~s}^{-1}$

10 In summary, five runs of the POM model are taken place from January 2001 to December 2003:

- a reference simulation without wind forcing;

- two runs forced by BOLAM 21 wind, with the constant and the variable value of the drag coefficient;

- two runs forced by BOLAM 7 wind, again with the same constant and variable value of the drag coefficient.

\subsection{Cluster analysis}

Cluster analysis is a numerical technique which tries to allocate objects into groups, or clusters, following some kind of similarity criterion based on the definition of a distance
OSD

7, 207-249, 2010

\section{Wind forcing effects} on coastal circulation

P. De Gaetano et al.

\section{Title Page}

Abstract Introduction

Conclusions References

Tables

Figures

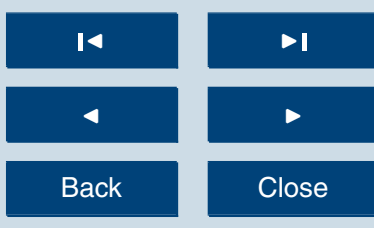

Full Screen / Esc

Printer-friendly Version

Interactive Discussion of objects in the same cluster can be considered more similar than a couple of objects belonging to distinct clusters (Everitt, 1977).

Cluster analysis is widely adopted in climatology for grouping stations or grid points to define climate regions and for the classification of wind regimes (e.g., Weber and 
Kaufmann, 1995). More recently, a two-stage clustering technique has been developed for the classification of mesoscale wind fields in both station and model data (Burlando et al., 2008; Burlando, 2008, respectively).

As regard oceanography, several studies apply cluster analysis to hydrological data. 5 For example, Becker and Pauly (1996) propose a regional classification of the SST anomaly fluctuations patterns in the North Sea. Warn-Varnasa et al. (2005), defining a water mass as a cluster of points consisting of temperature, salinity and depth values, study the water mass characteristics and distributions of the Wilkinson Basin area in the northwest corner of the Gulf of Maine.

10 To our knowledge, there are not yet applications of the cluster analysis on current velocity data. Nevertheless, there is no theoretical constraint to apply the same cluster methodology already used for the wind data to the current ones, in order to identify and classify the typical current regimes of the studied area. This approach allows to identify both the typical wind regimes and the current ones, then, linking the results, helps to understanding the influence of the wind regimes on the circulation patterns.

Therefore, the cluster analysis is performed on the two data sets of wind (i.e. BOLAM 21 and BOLAM 7 runs) and on the five data sets of coastal current (i.e. no-wind forcing, BOLAM 21 wind forcing with the constant and the variable drag coefficient value, BOLAM 7 wind forcing with the same constant and variable drag coefficient value). 20 For each BOLAM simulation, we have 8696 wind patterns (i.e. one output every three hours for three years), while for each run of the POM model, the number of current patterns is 1087 (i.e. one output every day for three years).

Each data set is partitioned into $k$ clusters, following the clustering procedure applied by Burlando et al. (2008). Firstly, this procedure produces a tree-like structure (dendrogram) corresponding to the successive hierarchical merging of the patterns into a single final cluster. The choice of the final number of clusters representative of the main regimes is made on the basis of the values of the total variance, i.e. the sum of the cluster variances, when clusters merge along the tree-like structure of the dendogram. Indeed, as suggested by Kaufmann and Weber (1996), the value of the metric
OSD

7, 207-249, 2010

\section{Wind forcing effects on coastal circulation}

P. De Gaetano et al.

\section{Title Page}

Abstract Introduction

Conclusions References

Tables Figures

14

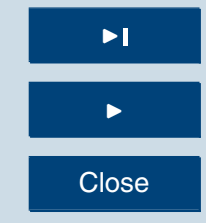

Full Screen / Esc

Printer-friendly Version

Interactive Discussion 
associated to the clustering algorithm, which is an indicator of information loss when two clusters gather together, can be assumed as an objective meter for this purpose.

To have a deeper understanding of the obtained clusters, the components of the horizontal vectors are recovered and the corresponding average vectors, i.e. the vectors 5 of the average components, are calculated for every cluster.

\section{Results}

We choose to present the results in five in-shore and three off-shore stations in the studied area (Fig. 6).

The distributions of the amplitude and direction of the wind at $10 \mathrm{~m}$ a.s.l. provided 10 by BOLAM 21 and BOLAM 7 for the three years at the eight stations, are computed and showed in Figs. 3 and 4, respectively. In the figures, the orography used by the model is also reported. Obviously, BOLAM 7 better resolves the orography than BOLAM 21. For example, the mountain pass of the Ligurian Appennines northeast of the Promontorio of Portofino is completely smoothed out in BOLAM 21. Nonetheless the 15 coast line of both BOLAM 21 and BOLAM 7 is about one hundred kilometers south of the real one. This diminishes the wind amplitude computed by the atmospheric model in the corresponding POM domain area, because the surface roughness of the sea is less than the land one. All BOLAM 21 wind roses present two preferential wind sectors centered around the northeast and south-southeast. Instead, BOLAM 7 wind roses present greater geographical variability. Offshore, the south-southeast component increases. Inshore, the frequent north-easterly wind rotates clockwise from station 1 to station 5 , following the topographical forcing.

Progressive vectors are used to demonstrate the difference between the two wind forcings (Fig. 5). Indeed, BOLAM 7 progressive vectors generally cover $13 \times 10^{4} \mathrm{~km}$ in 251087 days for $9 \times 10^{4} \mathrm{~km}$ in the BOLAM 21 cases. At stations 3, 6 and 7, the BOLAM 7 have a stronger northward component than their BOLAM 21 counterparts.
OSD

$7,207-249,2010$

\section{Wind forcing effects on coastal circulation}

P. De Gaetano et al.

\section{Title Page}

Abstract Introduction

Conclusions References

Tables Figures

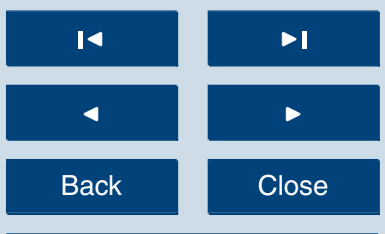

Full Screen / Esc

Printer-friendly Version

Interactive Discussion 
In regard to the POM results, progressive vectors of velocity of the simulated current without wind forcing in the aforementioned stations for the three simulated years, are showed in Fig. 6. Full dots represent the initial position of the current vectors and the progressive vector displacements are shown to scale. All off-shore stations show the 5 north-westward transport observed in the past literature (Astraldi and Manzella, 1983), while stations 1, 2 and 4 reveal current separation and eddy formation around the cape (Doglioli et al., 2004a).

For the following three scenarios, no-wind, BOLAM 21 and BOLAM 7 wind forcing with the constant value of $C_{\mathrm{D}}$, the progressive vectors of the simulated current in the 10 in-shore and off-shore stations are showed in Fig. 7. Black circles represent the initial positions of the progressive vectors. A cross, full dot and star are drawn every ninety days, starting from 1 January 2001 for no-wind, BOLAM 21 and BOLAM 7 wind forcing, respectively. The greater differences between the different forcing are seen in the inshore stations, where the effect of the wind favors the countercurrent and the eddy 15 formation. Considering the high resolution of wind forcing, it is possible to note greater rotation of the current in the in-shore stations especially in the 1, 3 and 4 ones. In the off-shore stations the higher resolution of the wind forcing does not seem to have an important effect.

Now the results using the variable $C_{\mathrm{D}}$ value are interpreted (Fig. 8). At the in-shore 20 stations, the difference between no-wind and wind forcing is greater than in the previous case (i.e. the constant $C_{\mathrm{D}}$ value). Moreover, in this case, while the difference between the wind forcing is small, the difference between the forced coastal circulation, especially at stations 3 and 5 , is much bigger.

In order to assess the variation in kinetic energy associated with the currents con- sidering the different forcing, the numerical domain is divided in four parts, with an idealized division between the in-shore and off-shore area and east and west zone of the promontory (dashed black line in Fig. 2). The average specific kinetic energies for different zones and scenarios are computed and reported in Table 1. For all zones, the average specific kinetic energy is greater considering wind forcing than no-wind
OSD

$7,207-249,2010$

\section{Wind forcing effects on coastal circulation}

P. De Gaetano et al.

\section{Title Page}

Abstract Introduction

Conclusions References

Tables Figures

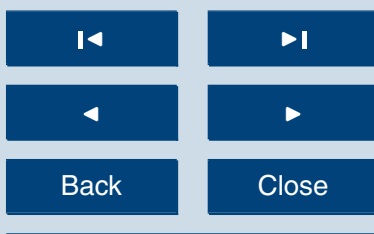

Full Screen / Esc

Printer-friendly Version

Interactive Discussion 
scenario. In fact considering the wind forcing, the specific kinetic energy increases especially in the in-shore zones. In particular, the kinetic energy of the in-west zone mostly increases than the other ones. Moreover, the greater increase of the kinetic energy for the in-shore west zone is observed considering the higher resolution wind forc5 ing, both with the constant and variable drag coefficient value. However, an increase of the kinetic energy in all considered zones is observed considering the variable value of drag coefficient.

Moreover, in order to assess the intensity of the eddy downstream to the cape, the mass transport trough the section A (Fig. 2) is computed. The average mass trans10 port through the section $A$ is negative in all simulated scenarios indicating an off-shore transport, in according to the presence of the eddy downstream the cape (Table 2). Considering the experiments with the wind forcing, this off-shore transport increases. Moreover in the experiment with BOLAM 7 forcing both with the constant and variable drag coefficient value, the mass transport is greater than in the same case with BO-

LAM 21 forcing. The greatest value of the off-shore transport is due to the experiment considering BOLAM 7 forcing with the variable $C_{\mathrm{D}}$ value.

In order to highlight the difference in the simulated coastal current considering the different forcings, along-shore and cross-shore components of the simulated current at station 5, for five considered scenarios, are computed following the methodology used by Astraldi and Manzella (1983) for in-situ data. Moreover, we distinguish between two directions of every velocity component. In Table 3, the maximum and average values of the simulated current for every direction, are reported. While the annual average coastal current (i.e. northwestward along-shore component) does not varies much considering the different scenarios, the annual average coastal countercurrent 25 (i.e. southeastward along-shore component) is more intense when higher-resolution wind forcing and variable drag coefficient value are considered. Both for the northeastward and southwestward cross-shore components, the annual average does not varies with the different simulated scenarios.
OSD

$7,207-249,2010$

\section{Wind forcing effects on coastal circulation}

P. De Gaetano et al.

\section{Title Page}

Abstract Introduction

Conclusions References

Tables Figures

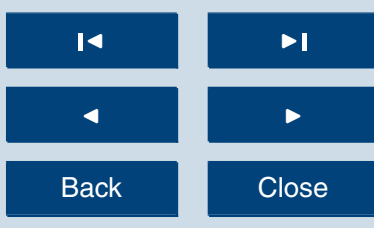

Full Screen / Esc

Printer-friendly Version

Interactive Discussion 
We perform the cluster analysis firstly on the two wind data sets (i.e. BOLAM 21 and BOLAM 7 runs) and then on the five coastal current data sets (i.e. no-wind forcing, BOLAM 21 forcing with the constant and variable $C_{\mathrm{D}}$ value, BOLAM 7 forcing with the same constant and variable $C_{\mathrm{D}}$ value).

5 In regard to the wind data, only the results obtained with the BOLAM 7 data set are reported. The reason of this choice is that the wind simulated by BOLAM 7 model better reproduces the wind dynamic of the area resulting in general less smooth and less uniform into the domain than the BOLAM 21 one, as showed by previous results.

The dendogram obtained by the cluster procedure is showed in Fig. 9 and corre10 sponds to the successive hierarchical merging of the wind patterns into a single final cluster.

The total variance of the subsequent cluster merging as a function of the number of remaining clusters is showed in Fig. 10. The diagram shows a strong reduction of the total variance at the steps corresponding to $k=2, k=3, k=6$ and $k=10$ clusters, while 15 it decreases slowly after the latter value. Also the wind data set considering BOLAM 21 model show a reduction of the total variance at the steps corresponding to $k=3$ and $k=6$ clusters. We choose $k=3$ because it represents the higher aggregation level characterized by very different clusters.

In Fig. 11, the monthly cycles of the resulting clusters for the BOLAM 7 wind are showed. Cluster $w 1$ shows a seasonal cyclicity in winter, while clusters $w 2$ and $w 3$ are mainly summer regimes. Cluster $w 1$ is very frequent every month and has a maximum in December and January. As far as summer regimes are concerned, cluster $w 2$ has a maximum in July and August, while the distribution of cluster $w 3$ is more spread than the other summer regime.

The cluster analysis performs on the five data sets of coastal current also generates three different clusters with a similar monthly distributions than the ones in Fig. 11. Moreover, for the current, the clusters are also distributed in the same way as for the wind: one cluster in winter and the other two in summer.
OSD

$7,207-249,2010$

\section{Wind forcing effects on coastal circulation}

P. De Gaetano et al.

\section{Title Page}

Abstract Introduction

Conclusions References

Tables Figures

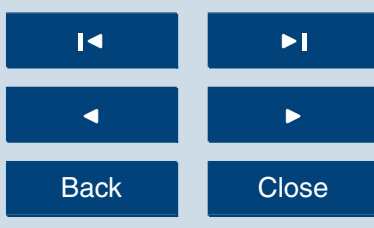

Full Screen / Esc

Printer-friendly Version

Interactive Discussion 
To have a deeper understanding of the three obtained clusters both for the wind and for the current data sets, the components of the horizontal velocity are recovered and the corresponding average vectors, i.e. the vectors of the average components, are calculated for every cluster. In the following, the resulting current regimes togheter 5 with the corresponding wind forcing (i.e. wind cluster with the more similar monthly distribution) are shown. In particular, only the current regimes with no-wind forcing, BOLAM 21 and BOLAM 7 wind forcing with the variable $C_{\mathrm{D}}$ value are showed. The results obtained with the constant value of $C_{\mathrm{D}}$ are quite similar to the no-wind forcing results.

10 The average wind field in cluster $w 1$ (Fig. 12a) corresponding to the winter regime, comes from north-east direction. The current cluster $c 1$ corresponds to winter regime and in every scenario it is characterized by a strong signal over the all domain and associated with high average current speeds toward the north-west. In the lee of the cape, considering the no-wind (Fig. 12b) and BOLAM 21 forcing (Fig. 12c) the eddy is 15 not present or not well developed as in the case of BOLAM 7 forcing (Fig. 12d).

For the summer regimes, the wind cluster w2 (Fig. 13a) shows an intense wind blowing from the south-east. In regard to the current clusters, for the no-wind forcing experiment (Fig. 13b), cluster $c 2$ is characterized by a northwestward transport more intense near the coast. In the experiments with the wind forcing, a countercurrent in 20 outh-east direction is present in-shore and the average current amplitude with BOLAM 7 wind forcing (Fig. 13d) than with BOLAM 21 wind forcing (Fig. 13c).

The wind structure in cluster $w 3$ (Fig. 14a) is not constant within the domain, following an anticyclonic rotation of the wind which blows from the north-east in the eastern part of the domain and from the south-east in the western part. Note that the average an intense current off-shore, which can be observed in every simulated scenario. Considering wind forcing, a weak coastal countercurrent is formed and considering BOLAM 7 wind forcing (Fig. 14d), this countercurrent is more intense than with BOLAM 21 wind forcing (Fig. 14c), especially around the cape.
OSD

$7,207-249,2010$

\section{Wind forcing effects on coastal circulation}

P. De Gaetano et al.

\section{Title Page}

Abstract Introduction

Conclusions References

Tables Figures

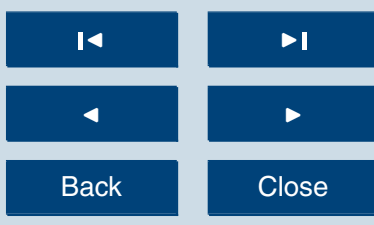

Full Screen / Esc

Printer-friendly Version

Interactive Discussion 


\section{Discussion}

In the studied area, the local winds are strongly influenced by the complex topography of the zone (Bruschi and Manzella, 1980; Pinardi and Masetti, 2000). The BOLAM 7 model uses an orography with a three times greater resolution than BOLAM 21 and it 5 permits to better resolve the local wind circulation of the area. Indeed, using this model, the southerly winds are more frequent and the events of southwesterly wind are also better resolved. Moreover, the winds blowing from the north is rotated in the east direction in the eastern part of the domain because the presence of the cape deflects these winds. This detailed feature is not reproduced by the BOLAM 21 model. Because

in both models.

In regard to the water circulation, at the same position of station 5, Astraldi and Manzella (1983) measured the current amplitude and direction with a currentmeter array providing annual mean values at 16,50 , and $95 \mathrm{~m}$. In order to provide a qualitative comparison between the in situ data and the model outputs, we can compute, from these data, depth-averaged annual values of -15.7 and $0.3 \mathrm{~cm} \mathrm{~s}^{-1}$ for along-shore (positive towards the south-east) and cross-shore (positive towards the north-east) components, respectively. The comparison can be only qualitative because the data are measured by Astraldi and Manzella (1983) many years ago and we consider a 2-D model. Comparing the model outputs and the in situ data, the modeled current results are underestimated. This is mainly due to two reasons: the Symphonie current outputs used at the incoming boundary are less intense than the in situ data and the modeled wind intensity used as forcing is underestimated.

However, in this study, the coastal model well reproduces the barotropic, northwestward along-shore transport presented in the observations (Bruschi and Manzella, 1980). Periods of flow reversal associated with southerly winds (Astraldi and Manzella, 1983) and the presence of anticyclonic eddies around the cape (Doglioli et al., 2004a) are also simulated. Moreover, since the primary aim of this study is an assessment of
OSD

$7,207-249,2010$

\section{Wind forcing effects} on coastal circulation

P. De Gaetano et al.

\section{Title Page}

Abstract Introduction

Conclusions References

Tables Figures

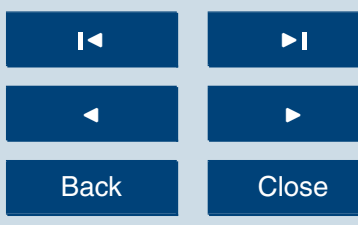

Full Screen / Esc

Printer-friendly Version

Interactive Discussion 
the importance of the higher resolution wind forcing on the coastal circulation and its effect is greater near the coast where the dynamic is two-dimensional, this modelling tool has proved successful. However, in further investigations, we intend to consider a three dimensional version of the model just to better assess the characteristics and 5 dimensions of the eddies (Doglioli et al., 2004a).

The greater effects of the higher resolution wind forcing near the coast is also highlighted considering the variations of the average specific kinetic energy. Indeed, it is maximum in the two in-shore zones and especially in the in-shore western zone, where the eddy is observed. In fact, the higher resolution wind forcing plays an important role 10 in resolving current separation and eddy formation, resulting in an intensification of the recirculations.

Considering the annual average mass transport through section A (Fig. 2), the greater transport is found in the experiment considering BOLAM 7 wind forcing with the variable $C_{\mathrm{D}}$ value, implying an eddy intensification. Also the countercurrent associated 15 with the southerly winds is more intense considering the higher resolution wind forcing. Considering the drag coefficient value varying with wind intensity, an increase of the current intensity, especially in the coastal area, is generally observed. So, for example, the exceptional events of southwesterly wind are crucial in producing an intensification of the countercurrent and eddy recirculations. Indeed, the effect of these winds on 20 the circulation can not be appreciated in the experiments with the constant drag coefficient because, since having a strong intensity, they are very rare. The presence of the countercurrent in the eastern Ligurian Sea is already observed by several authors (Bruschi and Manzella, 1980; Esposito and Manzella, 1982) but unfortunately there are no measurements in this area near the coast. Moreover, the only in situ data available 25 (Astraldi and Manzella, 1983), do not distinguish between current and countercurrent contributions to the average values, so that it is not possible to state what forcing is the most realistic one. With our results, it is highlighted that the countercurrent is mainly due to the wind forcing. A further confirmation of this conclusion is that Doglioli et al. (2004a), not considering the wind forcing, do not observed the coastal countercurrent
OSD

7, 207-249, 2010

\section{Wind forcing effects on coastal circulation}

P. De Gaetano et al.

\section{Title Page}

Abstract Introduction

Conclusions References

Tables Figures

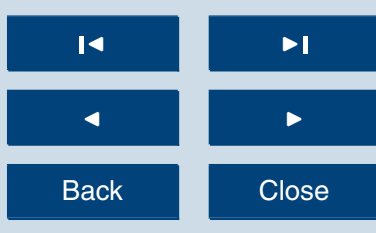

Full Screen / Esc

Printer-friendly Version

Interactive Discussion 
in east direction. So, it is reasonable to suppose that the higher resolution wind forcing gives more reliable description of the characteristics of the countercurrent.

Moreover, in order to highlight the differences occurring in the current circulation considering different wind forcings, we perform the cluster analysis on the wind data sets 5 and then on the current ones. We follow the methodology already tested and verified with wind data (Burlando, 2008; Burlando et al., 2008) in order to identify the main local regimes. We find the same seasonality both for the wind and the current patterns, corresponding to one winter and two summer scenarios. This seasonal variability of the Ligurian circulation is also shown in several works in the area (Astraldi et al., 1990, 10 1994; Astraldi and Gasparini, 1992; Echevin et al., 2002).

The cluster analysis on the wind and current data is performed independently on the different data sets and we find that the results are fluid-dynamically coherent. The winter regime is characterized by the wind blowing from the north-east. Considering the theoretical Ekman transport relation, the resulting current flows north-westward. 15 This produces an intensification of the general northwestward transport. And, indeed, the winter current cluster $c 1$ is characterized by this situation (Fig. 12). It is worth noting that the wind in the winter regime is more rotates eastward than shown by the wind roses (Fig. 4). This because, the average wind is the mean of the components of the wind patterns and, since the wind blowing from the north-northeast is very frequent and its patterns distribution is not symmetric, the mean and the mode values do not coincide.

In the summer regimes, the wind blows from the southeast producing a water accumulation against the coast upwind the cape. This water accumulation creates a pressure gradient from the coast to off-shore. The balance of the Ekman transport due to the wind and the pressure gradient give rise to the southeastward countercurrent shown in the summer clusters (Figs. 13 and 14). Moreover lee the cape, the eddy presence creates the southeastward current that is shown in Figs. 13 and 14 too.

For these reasons, we consider the wind and the current regimes, determinated by the cluster analysis, are fluid-dynamic coherent. Moreover, the cluster analysis
OSD

$7,207-249,2010$

\section{Wind forcing effects on coastal circulation}

P. De Gaetano et al.

\section{Title Page}

Abstract Introduction

Conclusions References

Tables Figures

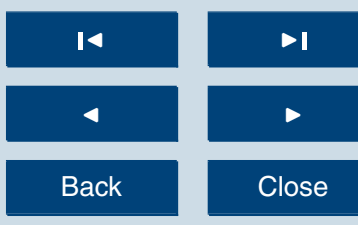

Full Screen / Esc

Printer-friendly Version

Interactive Discussion 
highlights that the coastal circulation in this area is driven by the wind and that the wind resolution has a strong effect on the currents near the coast.

\section{Conclusions}

As far as the numerical aspect of the present investigation, it provides a contribution in 5 two different directions: on the one hand, it contributes to our understanding of the role played by the wind resolution to resolve coastal circulation and eddy generation mechanism in presence of shelf and steep slope; on the other hand, it provides indications on the appropriate model configuration and parameter ranges to be used as a basis for future realistic modelling of the specific area.

10 Indeed, the results of the high-resolution coastal circulation model forced by the two versions of the atmospheric model BOLAM, well reproduces the observed northwestward along-shore transport and the periods of flow reversal in-shore associated with southerly winds. Moreover, the presence of anticyclonic eddies around the northwestern side of the cape are also simulated. It is shown that the wind forcing plays 15 a key role in enhancing the coastal dynamics and the eddy formation around the cape. Indeed, an intensification of the eddy and countercurrent formation is observed with the higher resolution wind forcing. Both the specific average kinetic energy and the annual average mass transport show an intensification of the eddy downstream of the cape and of the countercurrent. These effects are mainly due to the resolution of the orography used in the wind-forcing model. In the case of high resolution wind, the effect of the variable value of the drag coefficient with the wind speed has a great impact in-shore and causes an intensification of the countercurrent and of the eddy.

The performed cluster analysis highlights the season variability of the studied area. We find one winter and two summer regimes both for the wind and for the current pat25

terns. The winter regime is characterized by the presence of northeasterly winds that reinforce the general northwestward circulation. The formation of the eddy downstream of the cape can be observed considering the higher resolution wind forcing. During the
OSD

$7,207-249,2010$

Wind forcing effects on coastal circulation

P. De Gaetano et al.

\section{Title Page}

Abstract Introduction

Conclusions References

Tables Figures

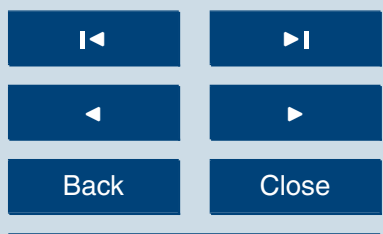

Full Screen / Esc

Printer-friendly Version

Interactive Discussion 
summer regimes, the countercurrent, associated to the southeasterly winds, appears only if the wind forcing is taken into account.

As a conclusion, it can be stated that in coastal areas characterized by complex topography, the higher resolution wind forcing plays a fundamental role to accurately 5 resolve the coastal circulation especially near the coast. For this reason, the use of an atmospheric model with even higher resolutions than in the present study, will be considered in future developments. In order to specifically analyze the eddy characteristics, a three dimensional description of the circulation will be taken into account. Moreover, the most important coastal circulation patterns of this area, identified through

10 a cluster analysis of the simulated flow fields, turn out to be significantly sensitive to the parameterization chosen for describing the wind-sea interaction, so that there is a real need for future systematic testing and comparison of numerical model results with measurement data.

Acknowledgements. The authors warmly thank Corrado Ratto and Roberto Festa for their help 15 and enlightening discussions. They are also grateful to ZiYuan Hu for kindly providing the Symphonie output data and for her helpful advices. More thanks to the ARPAL, Centro Funzionale Meteo-idrologico di protezione Civile della regione Liguria of Genoa (Italy), and in particular to Davide Sacchetti for kindly providing the BOLAM 21 and BOLAM 7 database and for his valuable support.

\section{References}

Aliani, S., Griffa, A., and Molcard, A.: Floating debris in the Ligurian Sea, North-Western Mediterranean, Mar. Pollut. Bull., 46, 1142-1149, 2003. 210

Astraldi, M. and Gasparini, G.: La circolazione costiera nel Mar Ligure orientale, Boll. Mus. Ist. Biol. Univ. Genova, 52(suppl), 317-331, 1986. 212

25 Astraldi, M. and Gasparini, G.: The seasonal characteristics of the circulation in the north Mediterranean Basin and their relationship with the atmospheric-climatic condition, J. Geophys. Res., 97(C6), 9531-9540, 1992. 211, 225

OSD

7, 207-249, 2010

\section{Wind forcing effects on coastal circulation}

P. De Gaetano et al.

\section{Title Page}

Abstract Introduction

Conclusions References

Tables Figures

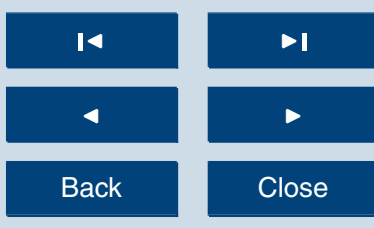

Full Screen / Esc

Printer-friendly Version

Interactive Discussion 
Astraldi, M. and Manzella, G.: Some observations on current measurements on the East Ligurian Shelf, Mediterranean Sea, Cont. Shelf Res., 2, 183-193, 1983. 211, 214, 215, 219, 220, 223, 224

Astraldi, M., Gasparini, G., and Manzella, G.: Temporal variability of currents in the Eastern Ligurian Sea, J. Geophys. Res., 95(C2), 1515-1522, 1990. 211, 215, 225

Astraldi, M., Gasparini, G., and Sparnocchia, S.: The seasonal and interannual variability in the Ligurian-Provencal basin, in: Seasonal and Interannual Variability of the Western Mediterranean Sea, edited by: La Violette, P. E., Coast. Estuar. Stud., 46, 93-113, 1994. 225

Baldi, A., Marri, P., and Schirone, A.: Applicazione di un modello per la simulazione del trasporto e della diluizione di inquinanti nelle acque costiere, Tech. rep., ENEA, RTI/AMB/GEM-MAR/97/04/RL2/A1.4, 1997. 215

Bastos, A., Kenyon, N., and Collins, M.: Sedimentry processes, bedforms and facies, associtated with a coastal headland: Portland Bill, Southern UK, Mar. Geol., 187, 235-258, 2002. 209

Bastos, A., Collins, M., and Kenyon, N.: Water and sediment movement around a coastal headland: Portland Bill, Southern UK, Ocean Dynam., 53, 309-321, 2003. 209

Becker, G. and Pauly, M.: Sea surface temperature changes in the North Sea and their causes, ICES J. Mar. Sci., 53, 887-898, 1996. 217

Blumberg, A. and Mellor, G.: A description of a three-dimensional coastal ocean circulation model, in: Three-Dimensional Coastal Ocean Models, edited by: Heaps, N., American Geophysical Union, Washington, DC, 4, p. 208, 1987. 214

Boyer, D. and Tao, L.: On the motion of linearly stratified rotating fluids past capes, J. Fluid Mech., 180, 429-449, 1987. 209

Bruschi, A. and Manzella, G.: Wind and current autumnal data series analysis on the Ligurian continental shelf, Nuovo Cimento C, 3(2), 151-164, 1980. 212, 214, 223, 224

Bunker, A.: Wintertime interactions of the atmosphere with the Mediterranean Sea, J. Phys. Oceanogr., 2, 225-238, 1972. 211

Burlando, M.: The synoptic-scale surface wind climate regimes of the Mediterranean Sea according to the cluster analysis of ERA-40 wind fields, Theor. Appl. Climatol., 96, 69-83, 2008. 210, 217, 225

Burlando, M., Antonelli, M., and Ratto, C.: Mesoscale wind climate analysis: identification of anemological regions and wind regimes, Int. J. Climatol., 28(5), 629-641, 2008. 217, 225

Buzzi, A., Fantini, M., Malguzzi, P., and Nerozzi, F.: Validation of a limited area model in cases

\section{Wind forcing effects on coastal circulation}

P. De Gaetano et al.

\section{Title Page}

Abstract Introduction

Conclusions References

Tables

Figures

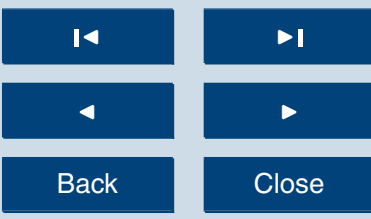

Full Screen / Esc

Printer-friendly Version

Interactive Discussion 
of Mediterranean cyclogenesis: surface fields and precipitation scores, Meteorol. Atmos. Phys., 53, 137-153, 1994. 212

Buzzi, A., Tartaglione, N., and Malguzzi, P.: Numerical simulations of the 1994 Piedmont flood: role of orography and moist processes, Mon. Weather Rev., 126(9), 2369-2383, 1998. 213

5 Castelao, R. and Barth, J.: The relative importance of wind strength and alongshelf bathymetric variations on the separation of a coastal upwelling jet, J. Phys. Oceanogr., 36, 412-425., 2006. 208

Castelao, R. M. and Barth, J. A.: The role of wind stress curl in jet separation at a cape, J. Phys. Oceanogr., 37, 2652-267, doi:10.1175/2007JPO3679.1, 2007. 208

10 Castellari, S., Pinardi, N., and Leanman, K.: Simulation of water mass formation processes in the Mediterranean Sea: Influence of the time frequancy of the atmospheric forcing, J. Geophys. Res., 105, 24157-24181, 2000. 211

Charnock, H.: Wind stress on a water surface, Q. J. Roy. Meteor. Soc., 81, 639-640, 1955. 213

Chèruy, F., Speranza, A., Sutera, A., and Tartaglione, N.: Surface winds in the Euro-

15 Mediterranean area: the real resolution of numerical grids, Ann. Geophys., 22, 4043-4048, 2004, http://www.ann-geophys.net/22/4043/2004/. 213

Chiswell, S. and Roemmich, D.: The east cape current and two eddies: a mechanism for larval retention?, N. Z. J. Mar. Freshwat. Res., 32, 385-397, 1998. 209

20 Coutis, P. and Middleton, J.: The physical and biological impact of a small island wake in the deep ocean, Deep-Sea Res. Pt. I 49(8), 1341-1361, 2002. 209

Csanady, G.: Circulation in the Coastal Ocean, D. Reidel Publishing Company, Kluwer Group, Dordrech, Holland, 1982. 216

Davies, P., Dakin, J., and Falconer, R.: Eddy formation behind a coastal headland, J. Coast. 25 Res., 11, 154-167, 1995. 209

De Gaetano, P., Doglioli, A., Magaldi, M., Vassallo, P., and Fabiano, M.: FOAM, a new simple benthic degradative module for the LAMP3D model: an application to a Mediterranean fish farm, Aquac. Res., 39, 1229-1242, doi:10.1111/j.1365-2109.2008.01990.x, 2008. 209, 210

Denniss, T., Middleton, J., and Manasseh, R.: Recirculation in the lee of complicated headlands: a case study of Bass Point, J. Geophys. Res., 100, 16087-16100, 1995. 209

Doglioli, A., Griffa, A., and Magaldi, M.: Numerical study of a coastal current on a steep slope in presence of a cape: the case of the Promontorio di Portofino, J. Geophys. Res., 109, C12033, doi:10.1029/2004JC002422, 2004a. 212, 214, 219, 223, 224

\section{OSD}

7, 207-249, 2010

\section{Wind forcing effects on coastal circulation}

P. De Gaetano et al.

\section{Title Page}

Abstract Introduction

Conclusions References

Tables Figures

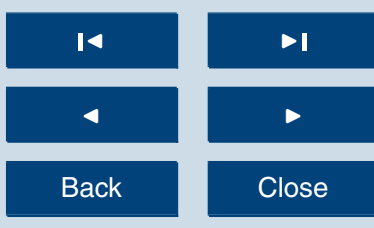

Full Screen / Esc

Printer-friendly Version

Interactive Discussion 
Doglioli, A., Magaldi, M., Vezzulli, L., and Tucci, S.: Development of a numerical model to study the dispersion of wastes coming from a marine fish farm in the Ligurian Sea (Western Mediterranean), Aquaculture, 231, 215-235, doi:10.1016/j.aquaculture.2003.09.030, 2004b. 209, 210

5 Echevin, V., Crèpon, M., and Mortier, L.: Simulation and analysis of the mesoscale circulation in the northwestern Mediterranean Sea, Ann. Geophys., 21, 281-297, 2003, http://www.ann-geophys.net/21/281/2003/. 225

Esposito, A. and Manzella, G.: Current circulation in the Ligurian Sea, in: Hydrodynamics of Semi-Enclosed Seas, edited by: Nihoul, J., Elsevier Scientific Publishing Company, Amster10 dam, 187-204, 1982. 209, 211, 212, 224

Everitt, B.: Cluster analysis, HEB, London, 1977. 216

Farmer, R., Pawlowicz, D., and Jiang, R.: Tilting separation flows: a mechanism for intense vertical mixing in the coastal ocean, Dynam. Atmos. Oceans, 36, 43-58, 2002. 209

Flather, R.: A tidal model of the nothwest European continental shelf, Mem. Soc. R. Sci. Liege, 15 Ser. 6, 141-164, 1976. 214

Freeland, H.: The flow of a coastal current past a blunt headland, Atmos. Ocean, 28, 288-302, 1990. 209

Geleyn, J.: Interpolation of wind temperature and humidity values from model levels to the height of measurements, Tellus A, 40, 347-351, 1988. 213

20 Geyer, W.: Three-dimensional tidal flow around headlands, J. Geophys. Res., 98, 955-966, 1993. 209

Group, M.: Observation of formation of deep water in the Mediterranean sea, Nature, 227, 1037-1040, 1970. 211

Hayward, T. and Mantyla, A.: Physical, chemical and biological structure of a coastal eddy near Cape Mendocino, J. Mar. Res., 48, 825-850, 1990. 209

Herbaut, C., Mortier, L., and Crèpon, M.: A sensitivity study of the general circulation of the Western Mediterranean Sea, J. Phys. Oceanogr., 26, 65-84, 1996. 208

Hu, Z., Doglioli, A., Petrenko, A., Marsaleix, P., and Dekeyser, I.: Numerical simulations of eddies in the Gulf of Lion, Ocean Model., 28(4), 203-208, 2009. 215

30 John, M. and Pond, S.: Tidal plume generation around a promontory: effects on nutrient concentrations and primary productivity, Cont. Shelf Res., 12(2-3), 339-354, 1992. 209

Jones, O., Simons, R., Jones, E., and Harris, J.: Influence of seabed slope and Coriolis effects on the development of sandbanks near headlands, J. Geophys. Res., 111, C03020,

OSD

$7,207-249,2010$

\section{Wind forcing effects on coastal circulation}

P. De Gaetano et al.

Title Page

Abstract

Introduction

Conclusions References

Tables

Figures

I

14

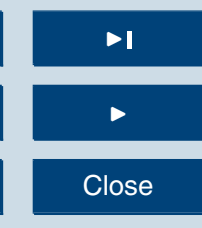

Back

Full Screen / Esc

Printer-friendly Version

Interactive Discussion 
doi:10.1029/2005JC002944, 2006. 209

Kaufmann, P. and Weber, R.: Classification of mesoscale wind fields in the MISTRAL field experiment, J. Appl. Meteorol., 35, 1963-1979, 1996. 217

Louis, J., Tiedke, M., and Geleyn, J.: A short history of the PBL parameterization at ECMWF, Proc. Workshop on Planetary Boundary Layer Parameterization, Shinfield Park, Reading, UK, ECMWF, 1982. 213

Malanotte-Rizzoli, P. and Bergamasco, A.: The circulation of the eastern Mediterranean: I, Oceanol. Acta, 12, 335-351, 1989. 208

Malanotte-Rizzoli, P. and Bergamasco, A.: The wind and thermally driven circulation of the eastern Mediterranean Sea: II. The Baroclinic case, Dynam. Atmos. Oceans, 15, 355-419, 1991. 208

Marsaleix, P., Auclair, F., Floor, J., Herrmann, M., Estournel, C., Pairaud, I., and Ulses, C.: Energy conservation issues in sigma-coordinate free-surface ocean models, Ocean Model., 20, 61-89, 2008. 215

15 May, P.: Climatological Flux Estimates in the Mediterranean Sea: Part I. Winds and Wind Stresses, NORDA Technical Report, NSTL, MS, 56 pp., 1982. 211

McCabe, R. and Pawlak, G.: Form drag due to flow separation at a headland, J. Phys. Oceanogr., 36(11), 2136-2152, 2006. 209

Mellor, G. and Yamada, T.: Development off a turbulence closure model for geophysical fluid problems, Rev. Geophys. Space Phys., 20, 851-875, 1982. 214

Molcard, A., Pinardi, N., Iskandarani, M., and Haidvogel, D.: Wind driven general circulation of the Mediterranean Sea simulated with a Spectral Element Ocean Model, Dynam. Atmos. Oceans, 35, 97-130, 2002. 208, 211

Moskalenko, L. V.: Steady state wind driven currents in the eastern half of the Mediterranean Sea, Okianologia, 4(14), 491-494, 1974. 208

Murdoch, R.: The effects of a headland eddy on surface macro-zooplankton assemblages north of Ontago Peninsula, New Zealand, Estuar. Coast. Shelf S., 29, 361-383, 1989. 209

Pattiaratchi, C., James, A., and Collins, M.: Island wakes and headland eddies: a comparison between remotely sensed data and laboratory experiments, J. Geophys. Res., 92, 783-794, 1986. 209

Pawlak, G., MacCready, P., Edwards, K., and McCabe, R.: Observations on the evolution of tidal vorticity at a stratified deep water headland, Geophys. Res. Lett., 30(24), 2234, doi:10.1029/2001JC001234, 2003. 209

\section{Wind forcing effects on coastal circulation}

P. De Gaetano et al.

\section{Title Page}

Abstract Introduction

Conclusions References

Tables Figures

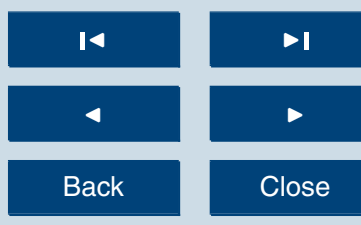

Full Screen / Esc

Printer-friendly Version

Interactive Discussion 
Pinardi, N. and Masetti, E.: Variability of the large-scale general circulation of the Mediterranean Sea from observations and modelling: a review, Palaeogeogr. Palaeoecol., 158, 153-173, 2000. 223

Pinardi, N. and Navarra, A.: Baroclinic wind adjustment processes in the Mediterranean Sea, Deep-Sea Res., 40(6), 1299-1326, 1993. 208

Pinardi, N., Allen, I., Demirov, E., De Mey, P., Korres, G., Lascaratos, A., Le Traon, P.-Y., Maillard, C., Manzella, G., and Tziavos, C.: The Mediterranean ocean forecasting system: first phase of implementation (1998-2001), Ann. Geophys., 21, 3-20, 2003, http://www.ann-geophys.net/21/3/2003/. 215

Pingree, R.: The formation of the shambles and other banks by tidal stirring of the seas, J. Mar. Biol. Ass. UK, 58, 211-226, 1978. 209

Rankin, K., Mullineaux, L., and Geyer, W.: Transport of juvenile gem clams (Gemma gemma) in a headland wake, Estuaries, 17(3), 655-667, 1994. 209

Roughan, M., Mace, J., Largier, J., Morgan, S., Fisher, J., and Carter, M.: Subsurface recircu15 lation and larval retention in the lee of a small headland: a variation on the upwelling shadow theme, J. Geophys. Res., 110, C10027, doi:10.1029/2005JC002898, 2005. 209

Sadoux, S., Baey, J.-M., Fincham, A., and Renouard, D.: Experimental study of the stability of an intemediate current and its interaction with a cape, Dynam. Atmos. Oceans, 31, 165-192, 2000. 209

20 Salmona, P. and Veradi, D.: The marine protected area of Portofino, Italy: a difficult balance, Ocean Coast. Manage., 44, 39-60, 2001. 210

Signell, R. and Geyer, W.: Transient eddy formation around headlands, J. Geophys. Res., 96, 2561-2575, 1991. 209

Taupier-Letage, I. and Millot, C.: General hydrodynamical features in the Ligurian Sea inferred from the DYOME experiment, Oceanol. Acta, 9(2), 119-131, 1986. 211

Verron, J., Davies, P. A., and Dakin, J. M.: Quasigeostrophic flow past a cape in a homogeneous fluid, Fluid Dyn. Res., 7, 1-21, 1991. 209

Warn-Varnasa, A., Gangopadhyayb, A., Hawkinsc, J., and Robinsond, A.: Wilkinson Basin area water masses: a revisit with EOFs, Cont. Shelf Res., 25(2), 277-296, 2005. 217

30 Weber, R. and Kaufmann, P.: Automated classification scheme for wind fields, J. Appl. Meteorol., 34, 1133-1141, 1995. 216
OSD

7, 207-249, 2010

\section{Wind forcing effects on coastal circulation}

P. De Gaetano et al.

\section{Title Page}

Abstract Introduction

Conclusions

References

Tables

Figures

I

14

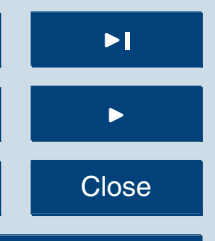

Full Screen / Esc

Printer-friendly Version

Interactive Discussion 
OSD

$7,207-249,2010$

\section{Wind forcing effects} on coastal circulation

P. De Gaetano et al.

Table 1. Average specific kinetic energy in the four zones of the domain (Fig. 2) for every simulated scenario.

\begin{tabular}{cccccc}
\hline & & \multicolumn{4}{c}{ Average specific kinetic energy $\left(10^{-8} \mathrm{~s}^{-2}\right)$} \\
& & \multicolumn{2}{c}{ zones } & \\
& in-W & in-E & off-W & off-E \\
\hline \multirow{2}{*}{ no-wind } & $0.94 \pm 1.01$ & $3.42 \pm 4.19$ & $1.68 \pm 2.65$ & $1.91 \pm 2.93$ \\
BOLAM 21 & $C_{\mathrm{D}}$ constant & $1.06 \pm 0.84$ & $3.80 \pm 4.23$ & $1.71 \pm 2.58$ & $2.02 \pm 2.94$ \\
& $C_{\mathrm{D}}$ variable & $1.72 \pm 2.05$ & $5.61 \pm 6.18$ & $2.42 \pm 2.39$ & $2.63 \pm 2.90$ \\
BOLAM 7 & $C_{\mathrm{D}}$ constant & $1.07 \pm 0.78$ & $3.67 \pm 4.30$ & $1.62 \pm 2.48$ & $1.96 \pm 2.89$ \\
& $C_{\mathrm{D}}$ variable & $1.78 \pm 2.32$ & $6.30 \pm 8.44$ & $1.95 \pm 2.39$ & $2.75 \pm 2.89$ \\
\hline
\end{tabular}

Title Page

Abstract

Introduction

Conclusions

References

Tables

Figures

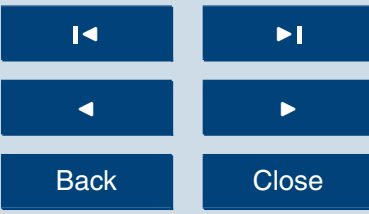

Full Screen / Esc

Printer-friendly Version

Interactive Discussion 
OSD

$7,207-249,2010$

\section{Wind forcing effects} on coastal circulation

P. De Gaetano et al.

Table 2. Annual average and standard deviation of mass transport trough the section A showed in Fig. 2 for every simulated scenario.

\begin{tabular}{ccccc}
\hline & & \multicolumn{3}{c}{$\begin{array}{c}\text { Mass transport }\left(10^{-2} \mathrm{~Sv}\right) \\
\text { simulated years }\end{array}$} \\
& & 2001 & 2002 & 2003 \\
\hline \multirow{2}{*}{ forcing } & no wind & $-0.39 \pm 1.10$ & $-0.32 \pm 0.77$ & $-0.27 \pm 1.88$ \\
BOLAM 21 & $C_{\mathrm{D}}$ constant & $-0.72 \pm 1.89$ & $-0.53 \pm 1.50$ & $-0.91 \pm 2.11$ \\
& $C_{\mathrm{D}}$ variable & $-1.50 \pm 3.25$ & $-1.06 \pm 2.95$ & $-2.12 \pm 3.89$ \\
BOLAM 7 & $C_{\mathrm{D}}$ constant & $-0.77 \pm 1.92$ & $-0.56 \pm 1.63$ & $-0.96 \pm 2.14$ \\
& $C_{\mathrm{D}}$ variable & $-1.80 \pm 3.82$ & $-1.39 \pm 3.09$ & $-2.27 \pm 4.29$ \\
\hline
\end{tabular}

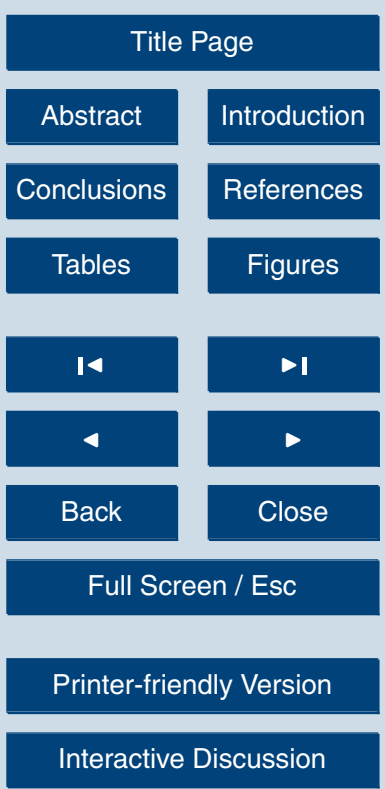


OSD

$7,207-249,2010$

\section{Wind forcing effects} on coastal circulation

P. De Gaetano et al.

Table 3. Comparison between the model outputs of current velocity in station 5 , considering the different scenarios.

\begin{tabular}{ccccccc}
\hline & Model Output & & \multicolumn{2}{c}{ along-shore $\left(\mathrm{cm} \mathrm{s}^{-1}\right)$} & \multicolumn{2}{c}{ cross-shore $\left(\mathrm{cm} \mathrm{s}^{-1}\right)$} \\
& & & north-west $(-)$ & south-east $(+)$ & north-east $(+)$ & south-west $(-)$ \\
\hline \multirow{2}{*}{ no wind } & & $\max$ & 21.7 & 14.1 & 2.9 & 6.5 \\
BOLAM 21 & \multirow{2}{*}{$C_{\mathrm{D}}$ constant } & ave \pm std & $8.7 \pm 5.4$ & $5.7 \pm 3.6$ & $0.3 \pm 0.3$ & $0.8 \pm 0.8$ \\
& & $\max$ & 21.4 & 15.2 & 3.2 & 6.5 \\
& & ave \pm std & $8.7 \pm 5.4$ & $6.1 \pm 3.6$ & $0.3 \pm 0.3$ & $0.8 \pm 0.8$ \\
& \multirow{2}{*}{$C_{\mathrm{D}}$ variable } & $\max$ & 25.6 & 18.7 & 3.2 & 6.5 \\
& & ave \pm std & $8.9 \pm 5.3$ & $7.1 \pm 4.8$ & $0.3 \pm 0.3$ & $0.8 \pm 0.8$ \\
BOLAM 7 & \multirow{2}{*}{$C_{\mathrm{D}}$ constant } & $\max$ & 21.5 & 18.4 & 6.7 & 6.4 \\
& & ave \pm std & $8.7 \pm 5.3$ & $6.3 \pm 3.8$ & $0.3 \pm 0.4$ & $0.9 \pm 0.9$ \\
& \multirow{2}{*}{$C_{\mathrm{D}}$ variable } & max & 23.0 & 18.9 & 6.7 & 6.4 \\
& & ave \pm std & $8.6 \pm 5.3$ & $8.0 \pm 5.2$ & $0.3 \pm 0.4$ & $0.9 \pm 0.9$ \\
\hline
\end{tabular}

Title Page

Abstract

Introduction

Conclusions

References

Tables

Figures

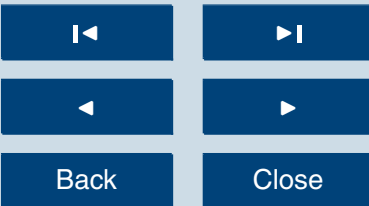

Full Screen / Esc

Printer-friendly Version

Interactive Discussion 
OSD

7, 207-249, 2010

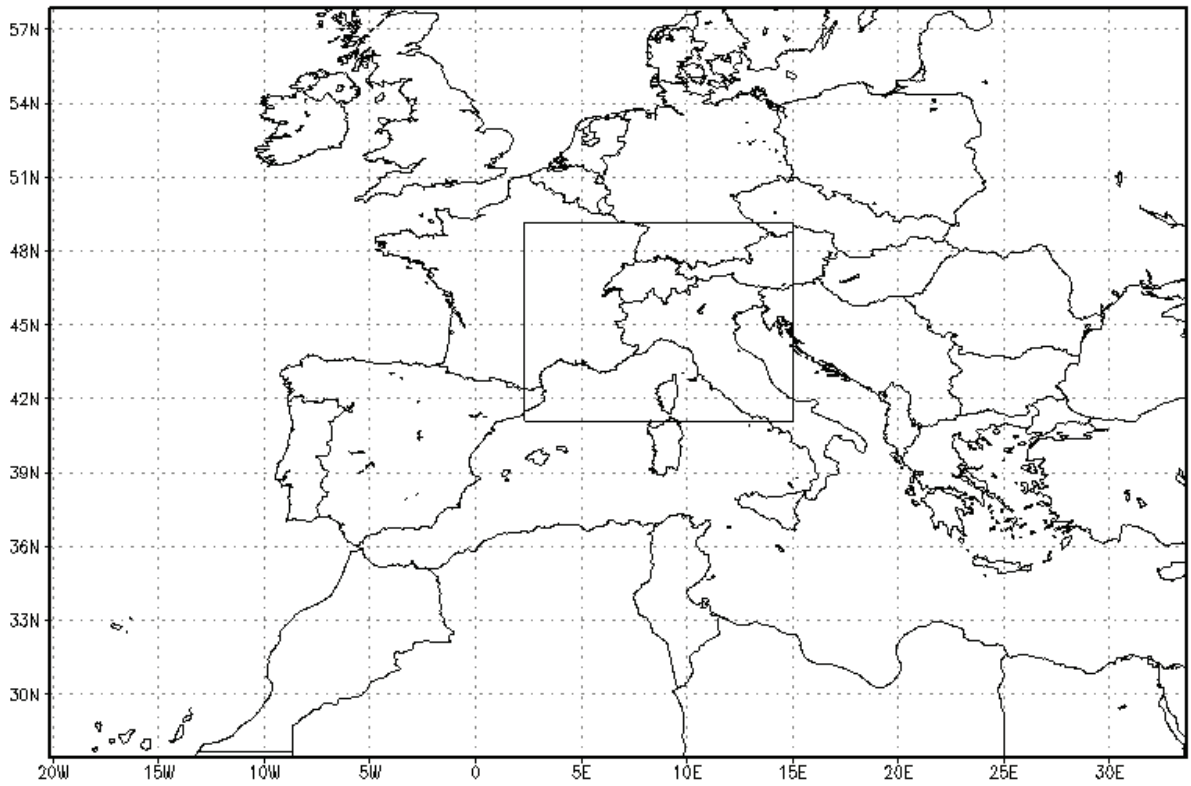

Fig. 1. BOLAM 21 domain and within the black rectangle BOLAM 7 domain. BOLAM 7 is one way nested into BOLAM 21.

\section{Wind forcing effects} on coastal circulation

\section{P. De Gaetano et al.}

Title Page

\section{Abstract}

Introduction

Conclusions

References

Tables

Figures

14

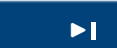

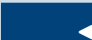

Back

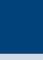

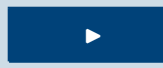

Close

Full Screen / Esc

Printer-friendly Version

Interactive Discussion 
OSD

7, 207-249, 2010

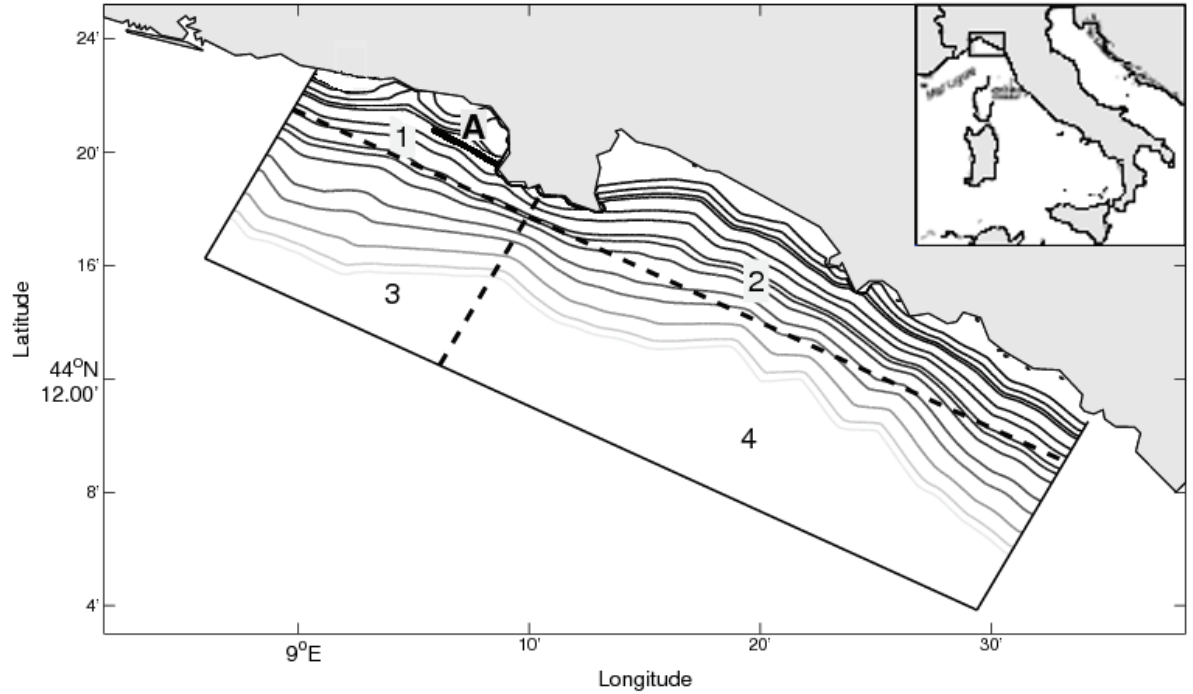

Wind forcing effects on coastal circulation

P. De Gaetano et al.

Title Page

Abstract

Introduction

Conclusions

References

Tables

Figures

14

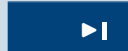

4

Back

$>$

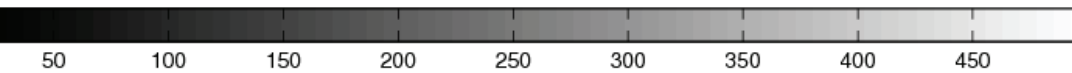

Close

Full Screen / Esc

Printer-friendly Version

Interactive Discussion

Fig. 2. Coastal model domain. Contour lines show the bathymetry $(\mathrm{m})$. Black line A represents the transport section. Numbers indicate the different zones of the model domain divided by the dashed black lines: (1) in-W, in-shore west (2) in-E, in-shore east (3) off-W, off-shore west and (4) off-E, off-shore east zone.

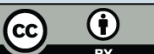


OSD

$7,207-249,2010$

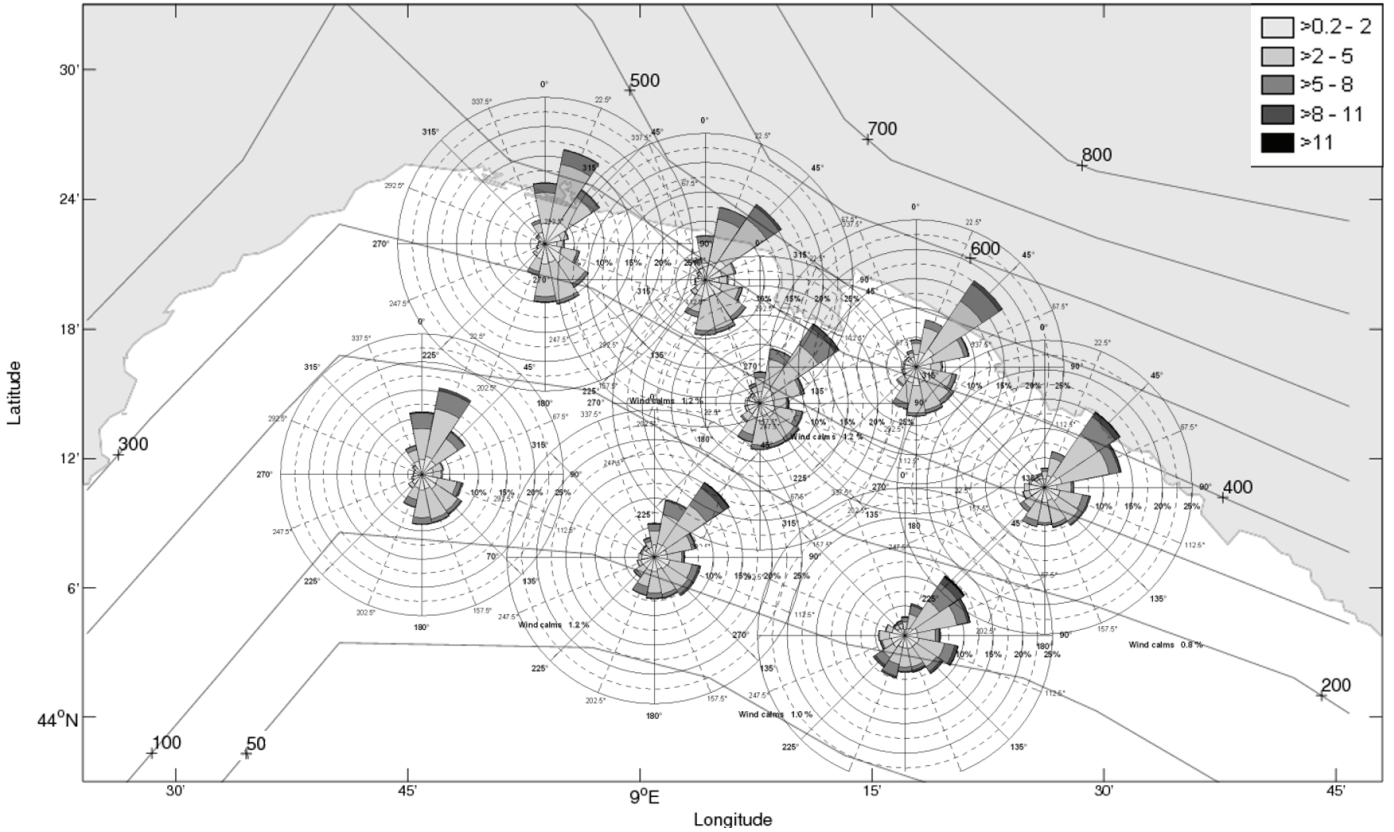

Fig. 3. Wind roses of the complete time series of the BOLAM 21 wind at $10 \mathrm{~m}$ a.s.l. in the eight considered stations. All the wind roses are drawn considering the same frequency scale i.e. between $0 \%$ and $25 \%$. Contour lines represent the orography used by the model $(\mathrm{m})$.

\section{Wind forcing effects on coastal circulation}

P. De Gaetano et al.

Title Page

\section{Abstract}

Introduction

Conclusions

References

Tables

Figures

14

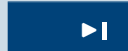

4

Back

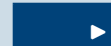

$\checkmark$

Close

Full Screen / Esc

Printer-friendly Version

Interactive Discussion 
OSD

$7,207-249,2010$

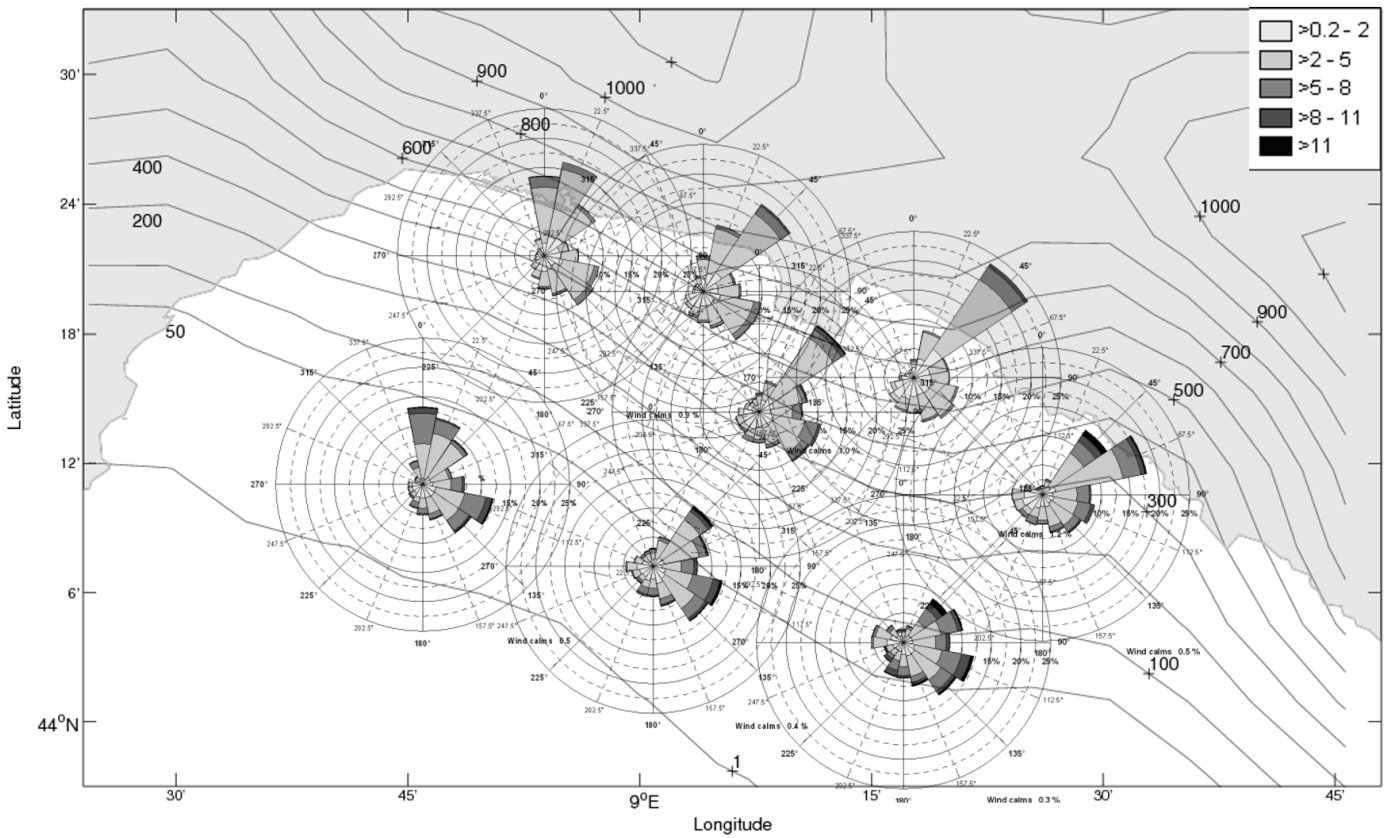

Fig. 4. Wind roses of the complete time series of the BOLAM 7 wind at $10 \mathrm{~m}$ a.s.l. in the eight considered stations. All the wind roses are drawn considering the same frequency scale i.e. between $0 \%$ and $25 \%$. Contour lines represent the orography used by the model $(\mathrm{m})$.

\section{Wind forcing effects on coastal circulation}

P. De Gaetano et al.

Title Page

\section{Abstract}

Introduction

Conclusions

References

Tables

Figures

14

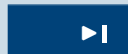

4

Back

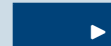

$\checkmark$

Close

Full Screen / Esc

Printer-friendly Version

Interactive Discussion 


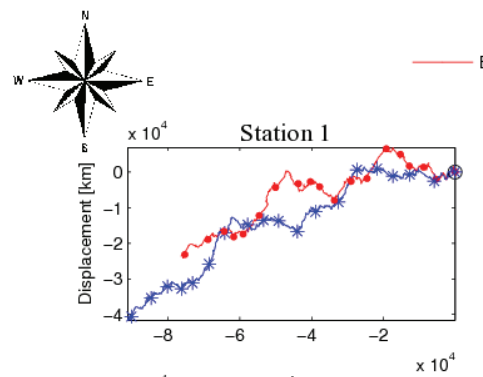

\section{OSD}

$7,207-249,2010$

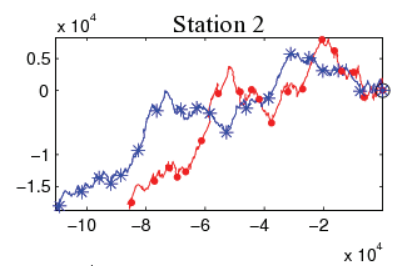

\section{Wind forcing effects on coastal circulation}

\section{P. De Gaetano et al.}
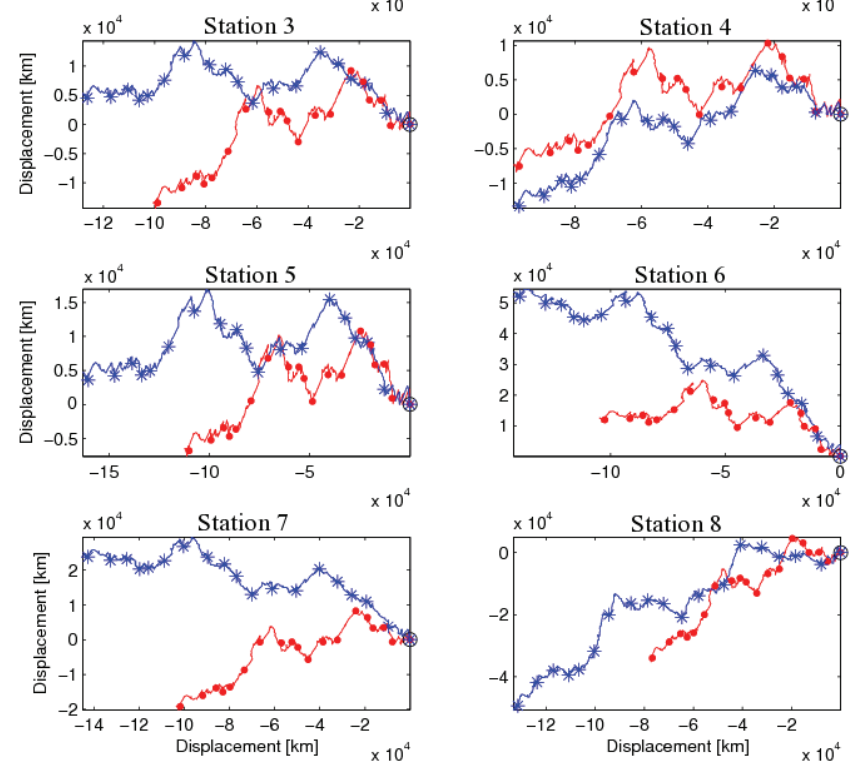

Fig. 5. Progressive vectors of the wind simulated by BOLAM 21 (red line) and BOLAM 7 (blue line) model in the in-shore and off-shore stations. The circles represent the starting positions. A full dot (BOLAM 21) and star (BOLAM 7) are drawn every 90 days starting from 1 January 2001. 
OSD

$7,207-249,2010$

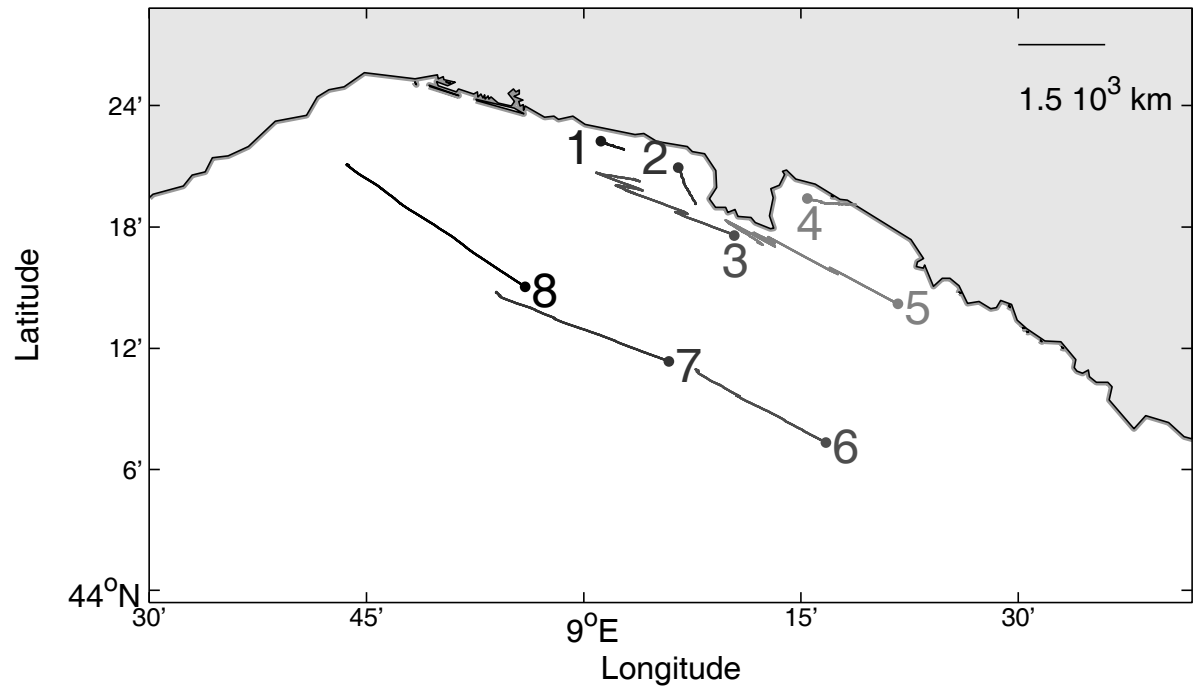

Fig. 6. Positions of the eight stations, where the in scale progressive vectors of current velocity computed by the model for the three simulated years without wind forcing are computed. Full dots represent the initial positions. The scale of the current progressive vectors is reported at the top right corner.

\section{Wind forcing effects} on coastal circulation

P. De Gaetano et al.

\section{Title Page}

\section{Abstract}

Introduction

Conclusions

References

Tables

Figures

14

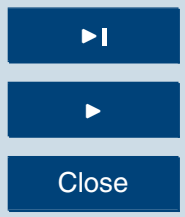

Back

Full Screen / Esc

Printer-friendly Version

Interactive Discussion 


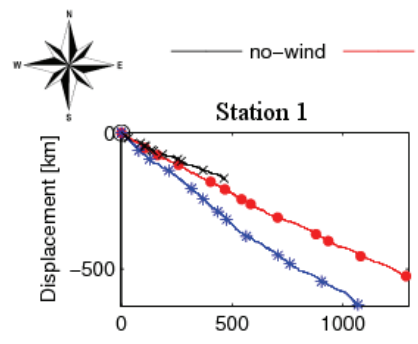

BOLAM $21 \longrightarrow$ BOLAM 7

OSD
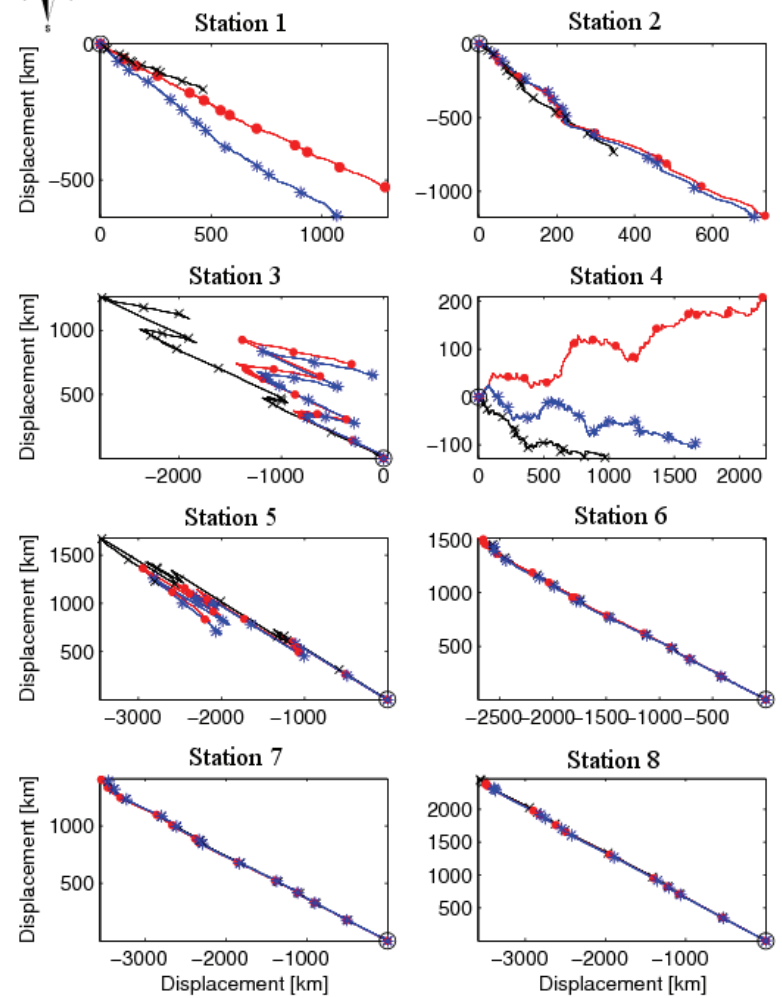

Fig. 7. Simulated current progressive vectors in the in-shore and off-shore stations. Black line represents the current progressive vector considering no-wind forcing, red line considering the BOLAM 21 forcing with the constant drag coefficient value and blue line considering the BOLAM 7 one with the same constant drag coefficient value. The circles represent the starting positions. A cross (no-wind), full dot (BOLAM 21 forcing) and star (BOLAM 7 forcing) are drawn every 90 days starting from 1 January 2001.
7, 207-249, 2010

\section{Wind forcing effects on coastal circulation}

P. De Gaetano et al.

Title Page

\section{Abstract}

Introduction

Conclusions

References

Tables

Figures

14

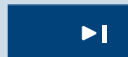

4

4

Back

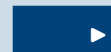

$>$

Close

Full Screen / Esc

Printer-friendly Version

Interactive Discussion 


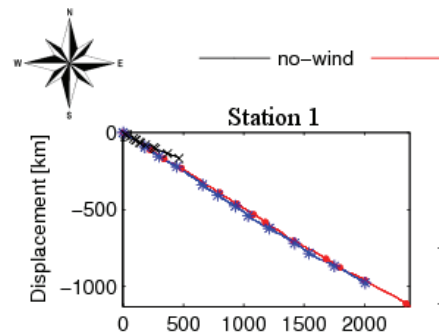

\section{OSD}

$7,207-249,2010$

\section{Wind forcing effects on coastal circulation}
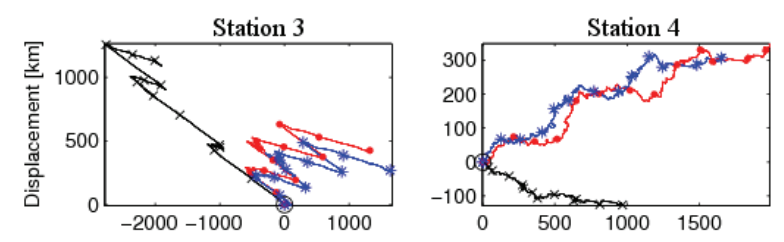

\section{P. De Gaetano et al.}

\section{Title Page}
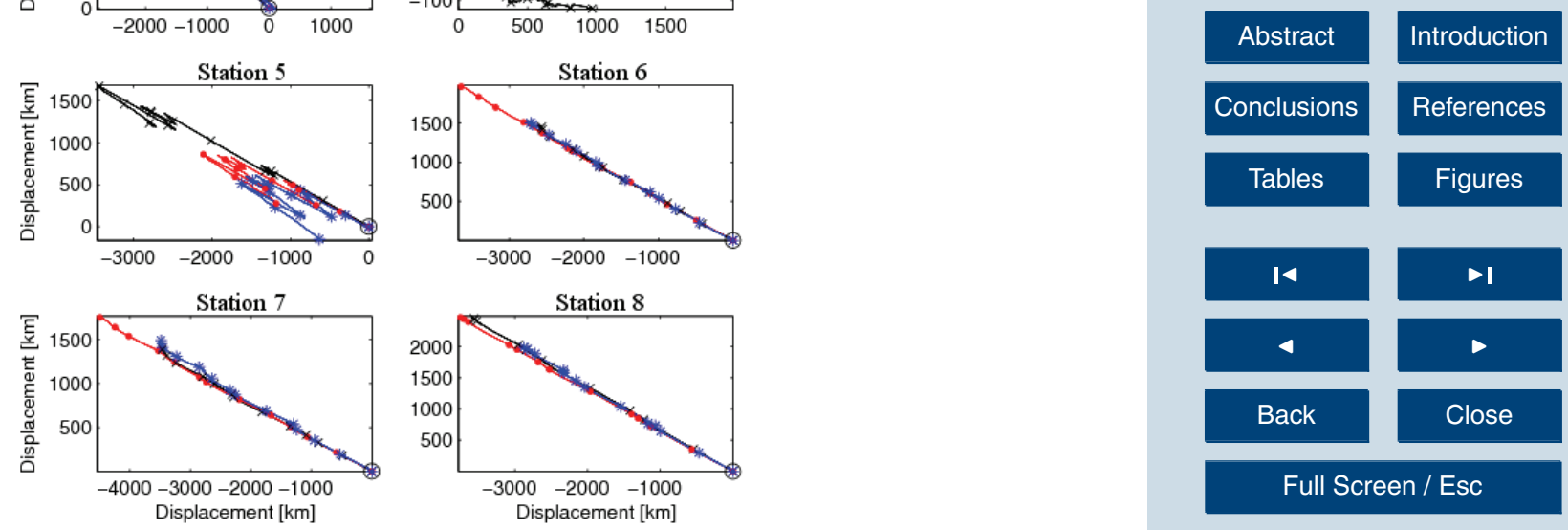

Fig. 8. Simulated current progressive vectors in the in-shore and off-shore stations. Black line represents the same current progressive vector considering no-wind forcing already showed in Fig. 7, red line considering the BOLAM 21 forcing with the variable drag coefficient value and blue line considering the BOLAM 7 one with the same variable drag coefficient value. The circles represent the starting positions. A cross, full dot and star are drawn every 90 days starting from 1 January 2001 for no-wind, BOLAM 21 and BOLAM 7 wind forcing, respectively. 


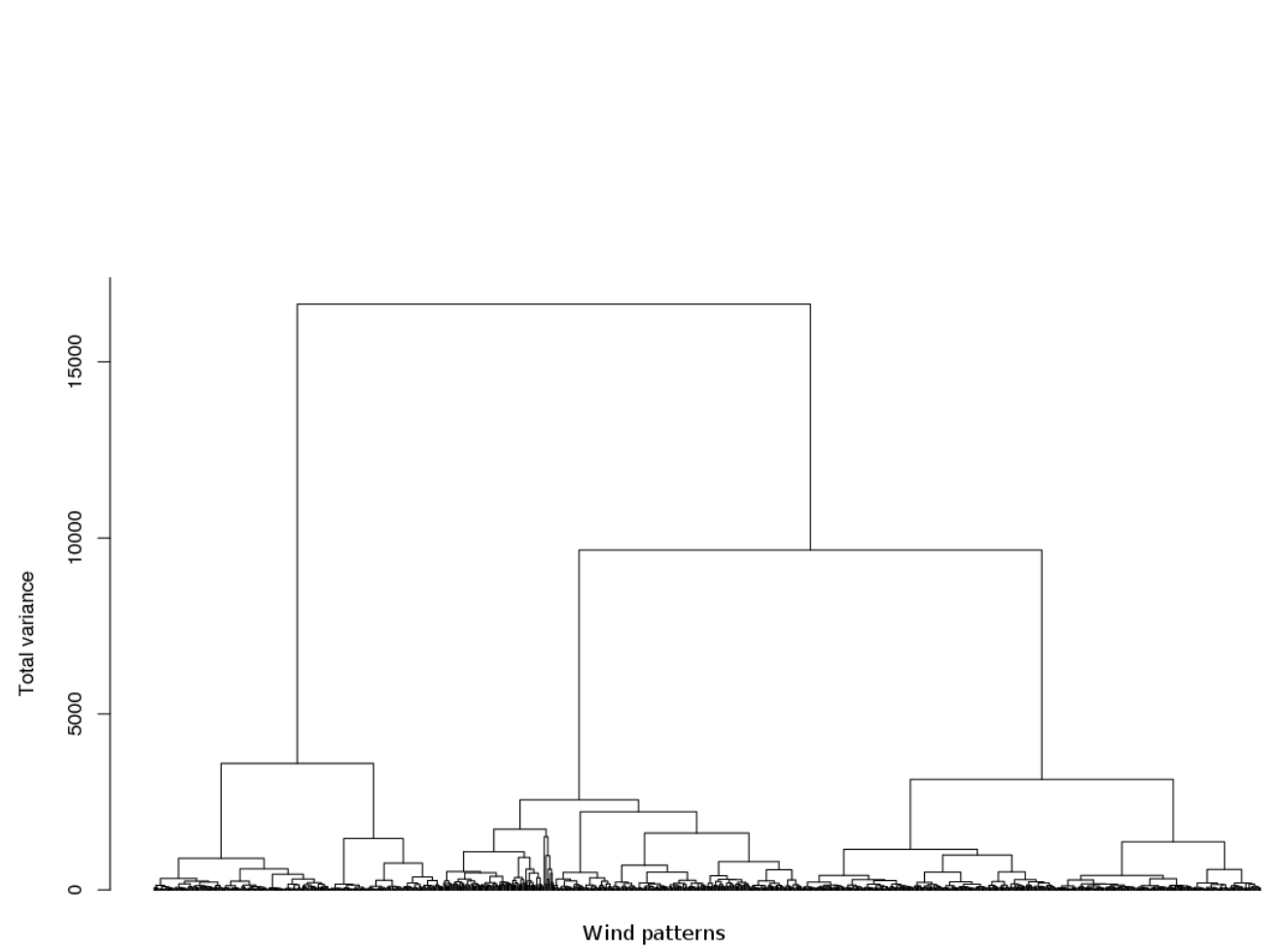

Fig. 9. Cluster dendrogram of successive aggregations between the wind patterns considering BOLAM 7 model.
OSD

7, 207-249, 2010

\section{Wind forcing effects} on coastal circulation

P. De Gaetano et al.

\begin{tabular}{|c|c|}
\hline \multicolumn{2}{|c|}{ Title Page } \\
\hline Abstract & Introduction \\
\hline Conclusions & References \\
\hline Tables & Figures \\
\hline & \\
\hline I4 & $>\mathbf{I}$ \\
\hline 4 & $\triangleright$ \\
\hline Back & Close \\
\hline Full Screen / Esc
\end{tabular}

Printer-friendly Version

Interactive Discussion 
OSD

7, 207-249, 2010

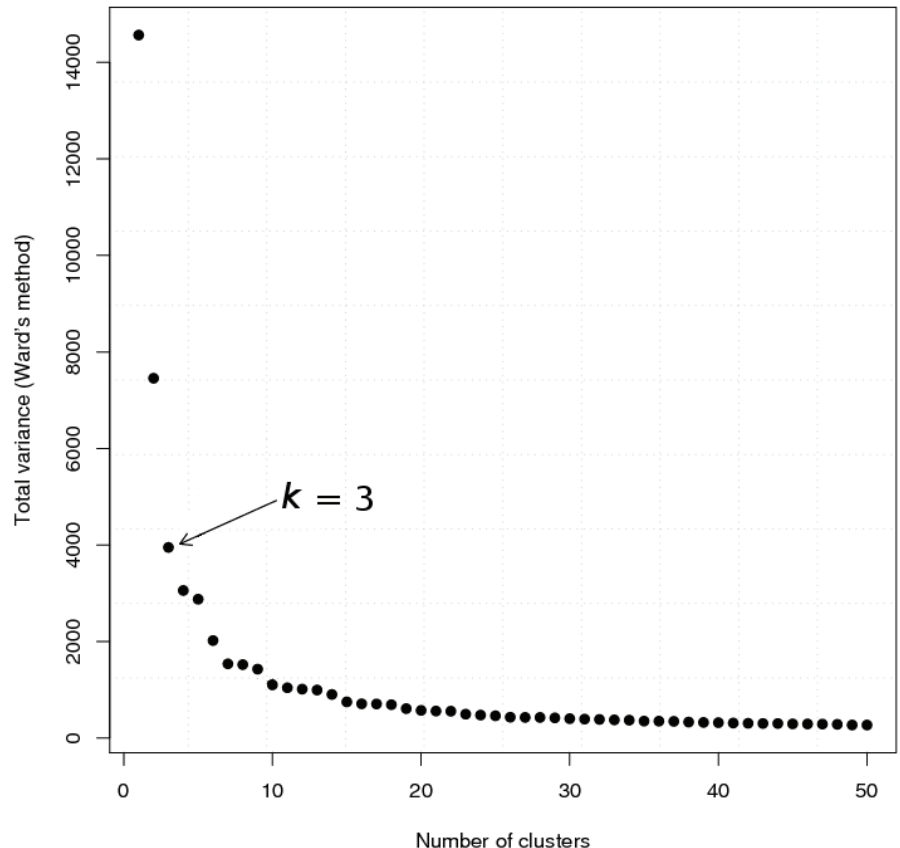

\section{Wind forcing effects} on coastal circulation

P. De Gaetano et al.

Title Page

\section{Abstract}

Introduction

Conclusions

References

Tables

Figures

14

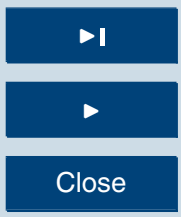

Back

Full Screen / Esc

Printer-friendly Version

Interactive Discussion

Fig. 10. Sum of cluster variances. Values of the total variance corresponding to successive cluster merging for the last 50 aggregations, for the wind data set considering BOLAM 7 model.

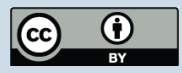




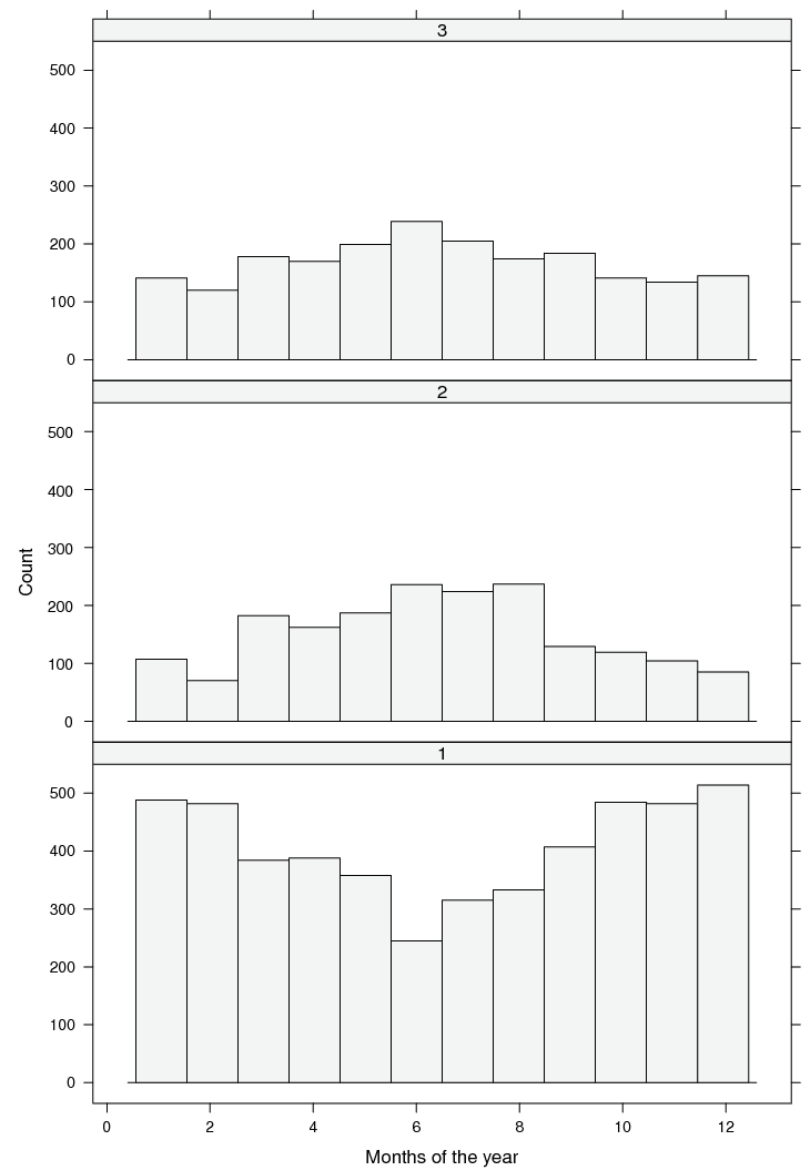

OSD

7, 207-249, 2010

Wind forcing effects on coastal circulation

P. De Gaetano et al.

Title Page

Abstract

Introduction

Conclusions

References

Tables

Figures

14

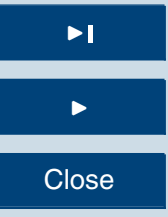

Back

Close

Full Screen / Esc

Printer-friendly Version

Interactive Discussion

Fig. 11. Monthly distributions of the three BOLAM 7 wind clusters corresponding to $k=3$ and representing the mean wind regimes in the area under study. 
OSD

$7,207-249,2010$
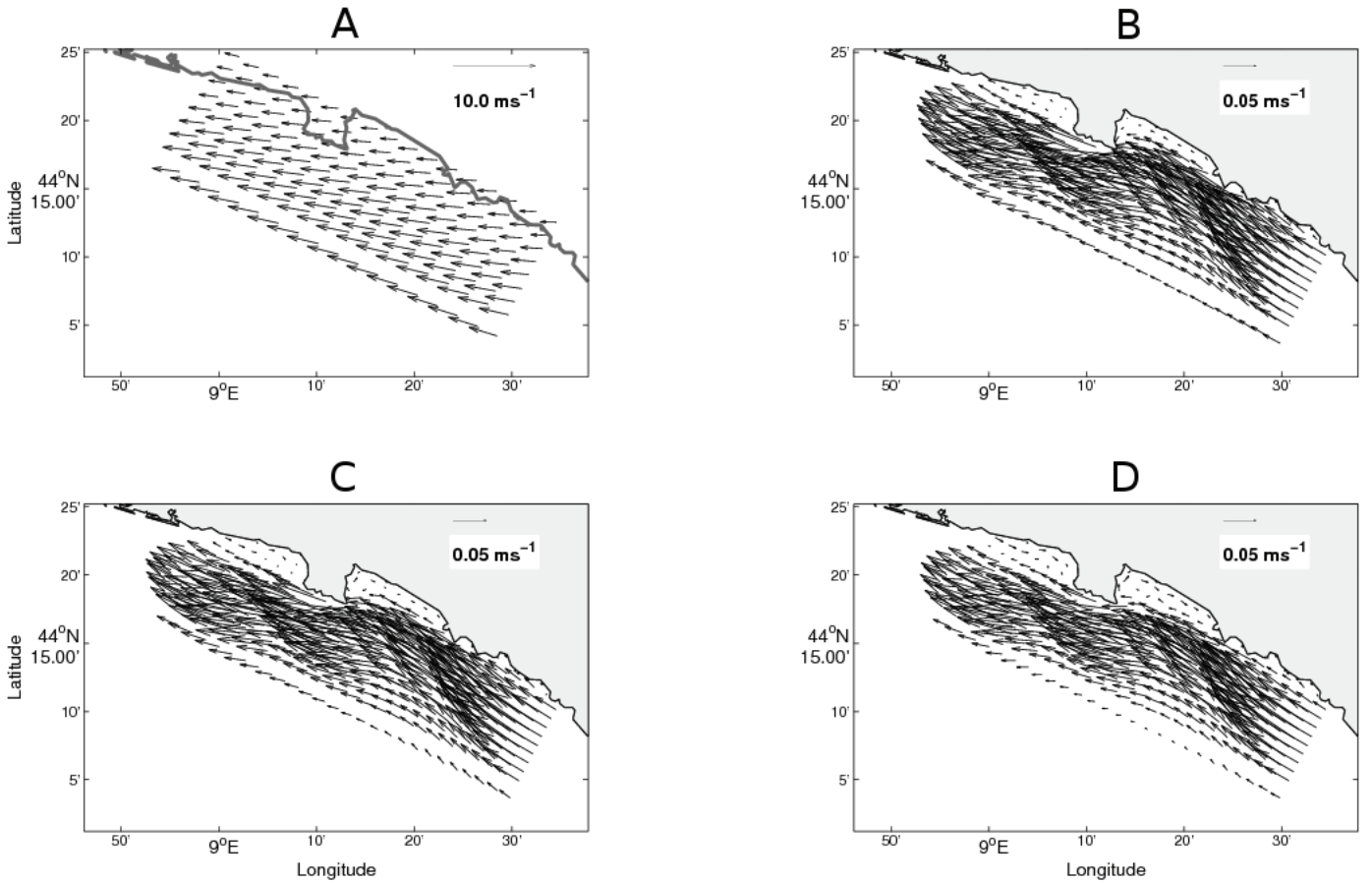

Fig. 12. Average wind vectors of cluster $w 1$ considering BOLAM 7 model $(\mathbf{A})$ and the average current vectors of cluster $c 1$ considering no-wind forcing (B), BOLAM 21 forcing with the variable $C_{\mathrm{D}}$ value $(\mathrm{C})$ and BOLAM 7 forcing with the variable $C_{\mathrm{D}}$ value (D).

\section{Wind forcing effects} on coastal circulation

P. De Gaetano et al.

\section{Title Page}

\section{Abstract}

Introduction

Conclusions

References

Tables

Figures

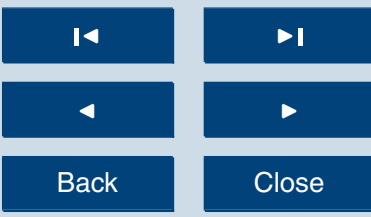

Full Screen / Esc

Printer-friendly Version

Interactive Discussion 
OSD

7, 207-249, 2010
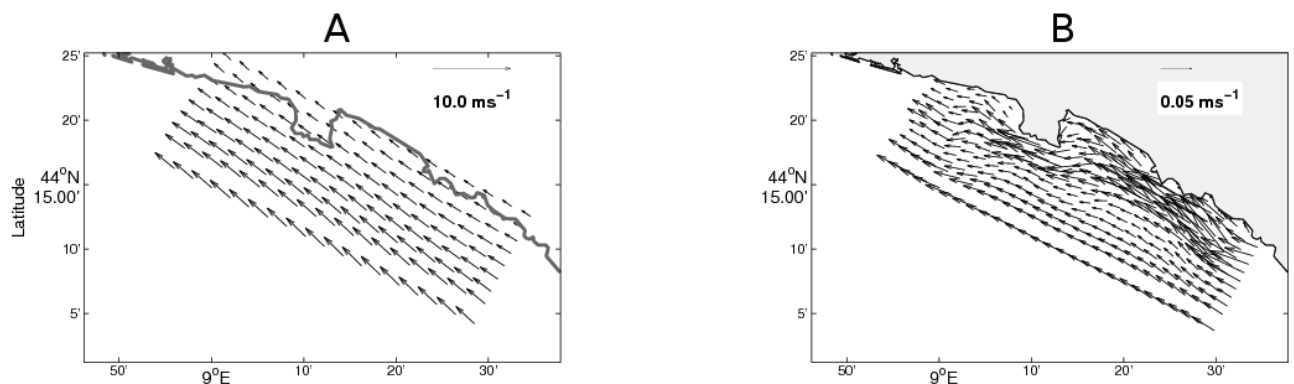

C

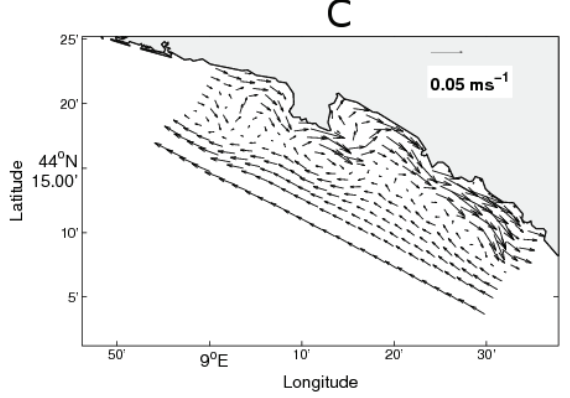

D

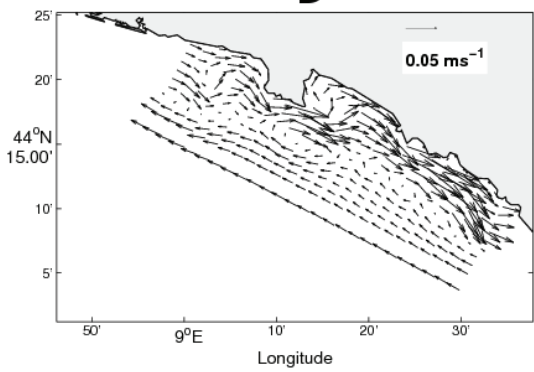

Wind forcing effects on coastal circulation

P. De Gaetano et al.

Title Page

Abstract

Introduction

Conclusions

References

Tables

Figures

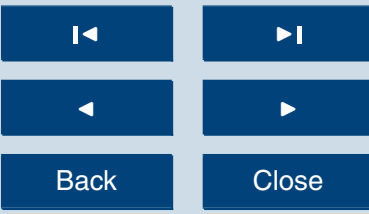

Full Screen / Esc

Printer-friendly Version

Interactive Discussion

Fig. 13. As Fig. 12 for the wind cluster $w 2$ and the current clusters $c 2$. 
OSD

$7,207-249,2010$
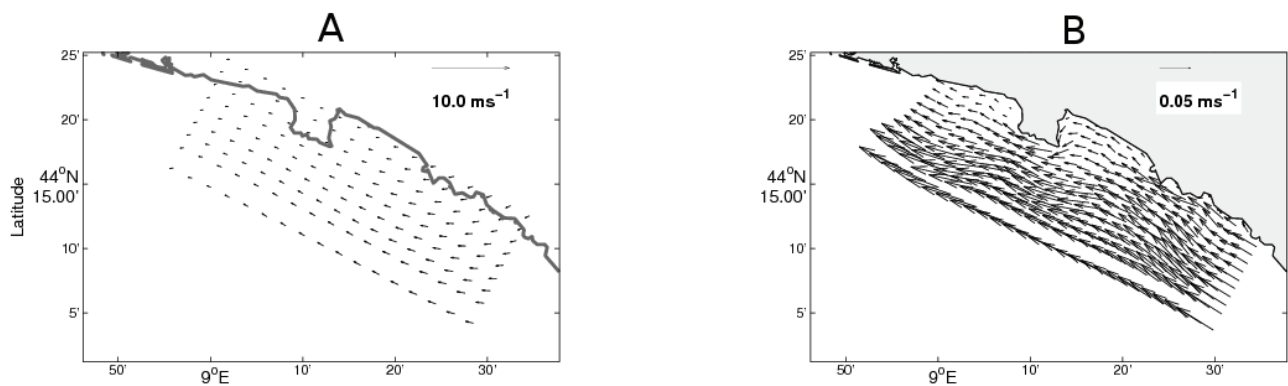

C

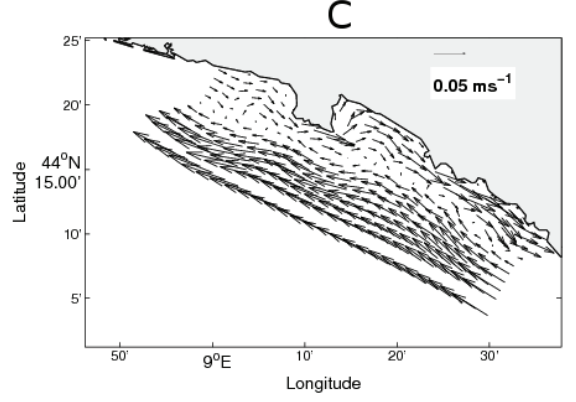

D

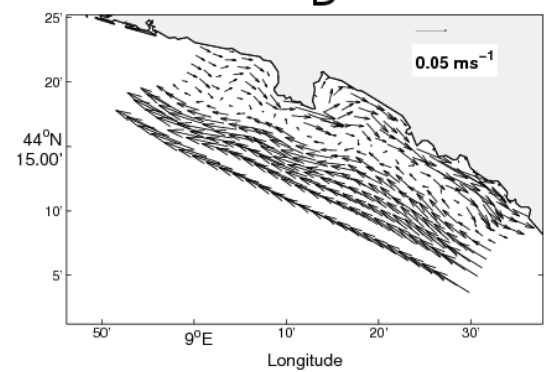

Wind forcing effects on coastal circulation

P. De Gaetano et al.

Title Page

Abstract

Introduction

Conclusions

References

Tables

Figures

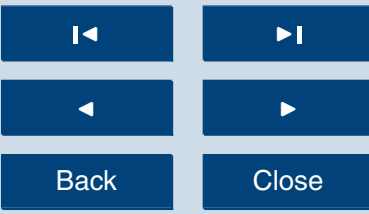

Full Screen / Esc

Printer-friendly Version

Interactive Discussion

Fig. 14. As Fig. 12 for the wind cluster $w 3$ and the current clusters $c 3$.

(C) (1) 